\title{
Factor momentum, option-implied volatility scaling, and investor sentiment
}

\author{
Klaus Grobys ${ }^{1}$ · James W. Kolari ${ }^{2}$. Jere Rutanen ${ }^{1}$
}

Revised: 16 June 2021 / Accepted: 22 June 2021 / Published online: 3 July 2021

(c) The Author(s) 2021

\begin{abstract}
Factor momentum produces robust average returns that exhibit a similar economic magnitude as stock price momentum. To the extent that the post-earnings announcement drift (PEAD) factor captures mispricing, winner factors earn profits from being long on underpriced stocks and short on overpriced stocks. Conversely, loser-factors' negative exposure to the PEAD factor suggests that loser factors capture mispricing by being long on overpriced stocks and short on underpriced stocks. Option-implied volatility scaling increases both the economic magnitude and statistical significance of factor momentum. Factor momentum is not exposed to the same crashes as stock price momentum and therefore could provide a hedge for stock price momentum crash risks. Also, factor momentum mispricing is more pronounced when investor sentiment is high.
\end{abstract}

Keywords Asset pricing · Factor momentum · Investor sentiment · Option-implied volatility scaling · VIX

JEL Classification $\mathrm{G} 12 \cdot \mathrm{G} 14$

\section{Introduction}

Momentum is a persistent asset pricing phenomenon that exists across different asset classes (Asness et al, 2013). Unlike many asset pricing anomalies, as documented in Hou et al (2020), momentum is confirmed by scientific replication. ${ }^{1}$ Unfortunately, Daniel and Moskowitz (2016) found that momentum payoffs are subject to large crashes that occur in panic states, after multi-year market drawdowns, and in periods of high market volatility when the prices of past losers embody a high premium. Studies by Barroso and Santa-Clara (2015), Daniel and Moskowitz (2016), and Moreira and Muir (2017) have shown that volatility timing can increase the Sharpe ratios of risk-managed momentum strategies; however, after correcting for a look-ahead bias, Liu et al (2019) found that their performance worsened substantially and could not outperform the market in general. ${ }^{2}$

Klaus Grobys

kgrobys@uva.fi

1 University of Vaasa, Vaasa, Finland

2 Department of Finance, Mays Business School, Texas A\&M University, College Station, TX, USA
Cross-sectional (CS) factor momentum, as documented in Arnott et al (2018), is a strategy that is long past winner factors and short past loser factors and subsumes various specifications of Moskowitz and Grinblatt's (1999) industrial momentum. In this regard, Gupta and Kelly (2019) and Ehsani and Linnainmaa (2019) explored the asset pricing implications of time-series (TS) factor momentum. Using spanning regressions, Ehsani and Linnainmaa augmented Fama and French's (2015) five-factor model by adding a TS factor momentum as an additional explanatory variable. The latter factor fully subsumed both traditional stock price momentum factor and Moskowitz and Grinblatt's (1999) industry-momentum factor.

Motivated by these two streams of momentum research, the present study has a threefold purpose. First, we investigate the profitability of option-implied, volatility-managed factor momentum strategies, including their payoff patterns

\footnotetext{
${ }^{1}$ Hou, Xue, and Zhang (2020) investigated 452 asset pricing anomalies and found that most anomalies fail to meet acceptable standards for empirical finance.

${ }^{2}$ Other studies that explore volatility scaling techniques include Dudler, Gmur and Malamud (2015), Jacobs, Regele, and Weber (2015), Kim, Tse, and Wald (2016), Baltas (2015), and Baltas and Kosowski (2015). Moreover, related studies on volatility-managed momentum strategies implemented using industrial portfolios include Plessis and Hallerbach, (2017), Grobys, Ruotsalainen, and Äijö (2018), and Grobys and Kolari (2020).
} 
in the presence of strong market reversals. ${ }^{3}$ We focus on a set of 11 factors that have been documented in the literature to be proxies for sources of equity systematic risk. In the sample period July 1963 to December 2019, we employ these factors to implement various CS and TS factor momentum strategies as well as corresponding option-implied volatilitymanaged counterparts. Risk-managed strategies are adjusted for risk by regressing them on various factor models commonly used in applied research. Second, after assessing the profitability of volatility-managed factor momentum strategies, we examine whether standard factor momentum strategies or their option-implied volatility-managed counterparts are subject to the same type of crash risks as stock price momentum strategies. Third, and last, we explore the origins of factor momentum. In this respect, we test whether changes in investor sentiment are associated with factor momentum returns.

Our study contributes to the literature in a number of ways. In this respect, we present new evidence on the effects of volatility-timing portfolios. As already discussed, while some authors postulate that volatility timing increases the profitability of traditional momentum strategies, Liu, Tang, and Zhou found evidence that casts doubt on the benefits of volatility timing. Given that volatility timing remains inconclusive, we add to the current discussion by proposing a novel approach using option-implied volatility to calculate the scaling factors. Also, we contribute evidence on the profitability of volatility-managing factor momentum strategies.

Breaking new ground, we explore the effect of strong market reversals during bear market regimes on the profitability of Ehsani and Linnainmaa's (2019) factor momentum strategies. Our findings enable us to re-assess the relevance of recent evidence on the momentum premium documented in Daniel and Moskowitz's (2016) study. Additionally, we investigate potential commonalities of momentum crashes with respect to traditional stock price momentum and recently proposed factor momentum strategies. ${ }^{4}$

\footnotetext{
${ }^{3}$ For instance, extraordinary market reversals were observed in the wake of the 2008-2009 financial crisis.

${ }^{4}$ Barroso and Santa-Clara (2015) and Moreira and Muir (2017) proposed strategies for volatility-timing momentum payoffs based on realized volatility. However, Novy-Marx (2014) has raised concern that timing investment in anomalies could be a data-mining issue. This possibility is corroborated by the facts that (1) anomalies tend to disappear after discovery (McLean and Pontiff, 2016) and (2) the vast majority of anomalies fail scientific replication (Hou, Xue, and Zhang, 2020). In this regard, Grobys, Ruotsalainen, and Äijö (2018) observed that, as studies of crash risks are by nature driven by rare observations, there is the possibility of over-fitting a small sample of extreme events. In this regard, the presence of the optionality effect documented by Daniel and Moskowitz (2016) in factor momentum would suggest a link in the tail risks of stock price momentum and factor momentum strategies.
}

Additionally, our study extends recent literature on factor momentum. In Ehsani and Linnainmaa (2019) and Gupta and Kelly (2019), factor momentum strategies are long factors with above-median returns and short factors with below-median returns. Following Arnott et al (2018), we implement both CS and TS factor momentum in an effort to re-assess the relevance of recent findings on the factor momentum premium. ${ }^{5}$ While these authors conjectured that factor momentum returns stem from mispricing, they do not explicitly address this issue. ${ }^{6}$ Here, we explore whether or not factor momentum strategies are driven by investor sentiment. We hypothesize that, to the extent that factor momentum returns arise from mispricing, significant exposure to the post-earnings announcement drift (PEAD) would suggest that investors underreact to earnings-related information.

Using a set of 11 factors, our results support those of Arnott et al (2018) and Ehsani and Linnainmaa (2019) with strong evidence for both CS and TS factor momentum. Our CS factor momentum strategy produces an average payoff corresponding to $1 \%$ per month with a Newey-West (1987) $t$-statistic of 5.89. Unlike stock price momentum (Daniel and Moskowitz, 2016), we document that factor momentum is not subject to optionality effects. These results are similar to those in Grobys and Kolari (2020), who argued that shortterm industrial momentum strategies are not exposed to the same tail risk as standard stock price momentum. This novel finding has important implications for asset management in the sense that the crash risk of stock price momentum can be hedged by combining stock price momentum and factor momentum.

Based on one-month lagged VIX values to scale factor momentum strategies, substantially higher payoffs are produced with more significant $t$-statistics. These findings corroborate earlier studies on the effects of risk-managed stock price momentum payoffs. Even after risk adjustment, the regression intercepts of most risk-managed strategies remain positive and statistically significant. For instance, regressing the short-term CS factor momentum strategy on its unscaled counterpart produces an average risk-adjusted payoff equal to 30 basis points per month with a highly significant $t$-statistic of 3.38. The economic magnitude and statistical significance of our results are similar to those for risk-managed industry momentum. ${ }^{7}$

\footnotetext{
5 Other relevant factor momentum studies include Avramov, Cheng, Schreiber, and Shemer (2017), Zaremba and Shemer (2018), Gupta and Kelly (2019), and Ehsani and Linnainmaa (2019).

${ }^{6}$ In this regard, Ehsani and Linnainmaa (2019) investigated the relation between 12-month lagged TS factor momentum and investor sentiment but did not account for testing CS factor momentum.

7 For example Grobys and Kolari (2020) found that risk-managed short-term industry momentum yields a risk-adjusted payoff of 33 basis points per month with a $t$-statistic of 3.71 .
} 
Table 1 Equity factors and seminal literature

\begin{tabular}{lll}
\hline Factor & Abbreviation & Original study \\
\hline Asset growth & ASSETG & Cooper et al. (2008) \\
Betting-against-beta & BAB & Frazzini and Pedersen (2014) \\
Book-to-market & BM & Rosenberg et al. (1985) \\
Cash flow-to-price & CFP & Lakonishok et al. (1994) \\
Dividend yield & DP & Litzenberger and Ramaswamy (1979) \\
Earnings-to-price & EP & Basu (1983) \\
High minus low (devil) & HML & Asness and Frazzini (2013) \\
Operating profitability & OP & Novy-Marx (2013) \\
Quality minus junk & QMJ & Asness et al. (2019) \\
Short-term reversals & STR & Jegadeesh (1990) \\
Momentum & UMD & Jegadeesh and Titman (1993)
\end{tabular}

Finally, our results suggest that the relation between investor sentiment and factor momentum performance is dependent on both the pre-formation period and how the factor momentum portfolios are constructed. For instance, Ehsani and Linnainmaa (2019), who examined the link between 12-month lagged TS factor momentum and investor sentiment, found that winner-factor portfolios have similar performance in high and low investor sentiment states. However, we find contradictory results-that is, winner-factor portfolios that are formed using 6-month lagged returns have significantly higher returns following periods of high investor sentiment, whereas the returns of loser-factor portfolios are not significantly negative following periods of low investor sentiment.

The next section describes the data. "Empirical Findings" section presents the empirical findings. "Conclusion" section contains concluding remarks.

\section{Data}

To simplify matters, we utilize 11 factors documented in the earlier literature to be proxies for sources of priced systematic risk in equities. Our analyses employ publicly available US market data, which can be readily replicated. $\mathrm{AQR}^{\prime} \mathrm{s}^{8}$ data library provides monthly return data for the betting-against-the-beta factor (BAB) from December 1930 to December 2019 and data for the quality-minus-junk factor (QMJ) from July 1957 to December 2019. Monthly return data for the high-minus-low devil factor $\left(\mathrm{HML}_{\mathrm{D}}\right)$ span the period from July 1926 to December 2019. Kenneth French's ${ }^{9}$ data library provides monthly portfolio returns for asset

\footnotetext{
8 https://www.aqr.com/insights/datasets.

${ }^{9}$ http://mba.tuck.dartmouth.edu/pages/faculty/ken.french/data_libra ry.html\#Research.
}

growth, book-to-market factor (B/M), cashflow-to-price factor $(\mathrm{CF} / \mathrm{P})$, dividend yield factor $(\mathrm{D} / \mathrm{P})$, earnings-to-price factor $(\mathrm{E} / \mathrm{P})$, stock price momentum factor (UMD), operating profitability factor (OP), and short-term reversals from July 1963 to December 2019. Data for the risk-free rate and market return data are obtained from French's data library also. Both AQR and French form the portfolios using all stocks traded in the NYSE and Nasdaq.

Table 1 lists the 11 factors used to form the factor momentum strategies in our study. An abbreviation for each factor is shown as well as coincident seminal research. Summary statistics for the factors are reported in Table 2. By keeping our set of factors parsimonious, we avoid redundancy, provide transparency, and ensure replicability of our results. ${ }^{10}$

To proxy market sentiment, we employ the investor sentiment index of Baker and Wurgler (2006). This data series is available from July 1965 to December 2018 on Wurgler's website. ${ }^{11}$ The investor sentiment index is based on 5 sentiment proxies. Unlike their study, the most recent dataset does not include the NYSE turnover as a proxy for investor sentiment. ${ }^{12}$ An orthogonalized investor sentiment index is obtained by regressing each proxy on growth in industrial production, growth in consumer durables, non-durables and services, and a NBER recession dummy variable. Figure 1 plots the end-of-month values of the investor sentiment index from July 1965 to December 2018. The shaded areas represent the NBER

\footnotetext{
${ }^{10}$ Even though Arnott, Clements, Kalesnik, Linnainmaa (2018) and Gupta and Kelly (2019) used 51 to 65 factors, the authors found that a set of 6 to 10 factors was sufficient to generate virtually identical profits. We infer that many factors are redundant.

${ }^{11} \mathrm{http}: / /$ people.stern.nyu.edu/jwurgler/.

12 The five proxies are discount on closed-end funds, dividend premium, equity share in new equity issues, number of IPOs, and the average first-day returns on IPOs.
} 
Table 2 Summary statistics for long-short factors

\begin{tabular}{lllllrrr}
\hline Factor & $\bar{r}(\%)$ & SD $(\%)$ & $t(\bar{r})$ & Max $(\%)$ & Min $(\%)$ & Skewness & Kurtosis \\
\hline EW Average & $\mathbf{0 . 3 7}$ & 1.45 & $(6.57)$ & 10.6 & -8.5 & 0.33 & 9.96 \\
ASSETG & $\mathbf{0 . 2 7}$ & 1.99 & $(3.58)$ & 9.6 & -6.9 & 0.31 & 4.62 \\
BAB & $\mathbf{0 . 8 2}$ & 3.25 & $(6.55)$ & 15.4 & -15.6 & -0.48 & 7.48 \\
BM & $\mathbf{0 . 3 1}$ & 2.81 & $(2.83)$ & 12.9 & -11.2 & 0.10 & 5.02 \\
CFP & $\mathbf{0 . 2 8}$ & 2.50 & $(2.95)$ & 11.4 & -12.0 & -0.11 & 5.57 \\
DP & 0.01 & 2.81 & $(0.07)$ & 10.6 & -11.5 & -0.05 & 4.33 \\
EP & $\mathbf{0 . 2 9}$ & 2.57 & $(2.96)$ & 9.6 & -13.0 & -0.04 & 5.37 \\
HML & $\mathbf{0 . 2 6}$ & 3.40 & $(2.02)$ & 27.0 & -18.0 & 0.89 & 11.63 \\
OP & $\mathbf{0 . 2 6}$ & 2.16 & $(3.13)$ & 13.3 & -18.3 & -0.31 & 15.44 \\
QMJ & $\mathbf{0 . 3 8}$ & 2.23 & $(4.47)$ & 12.4 & -9.1 & 0.22 & 5.89 \\
STR & $\mathbf{0 . 4 9}$ & 3.07 & $(4.20)$ & 16.2 & -14.6 & 0.38 & 8.72 \\
UMD & $\mathbf{0 . 6 5}$ & 4.19 & $(4.01)$ & 18.4 & -34.4 & -1.30 & 13.35 \\
\hline
\end{tabular}

Notes: Bold values indicate statistical significance at the $5 \%$ level.
Fig. 1 Investor sentiment index from July 1965 to December 2018
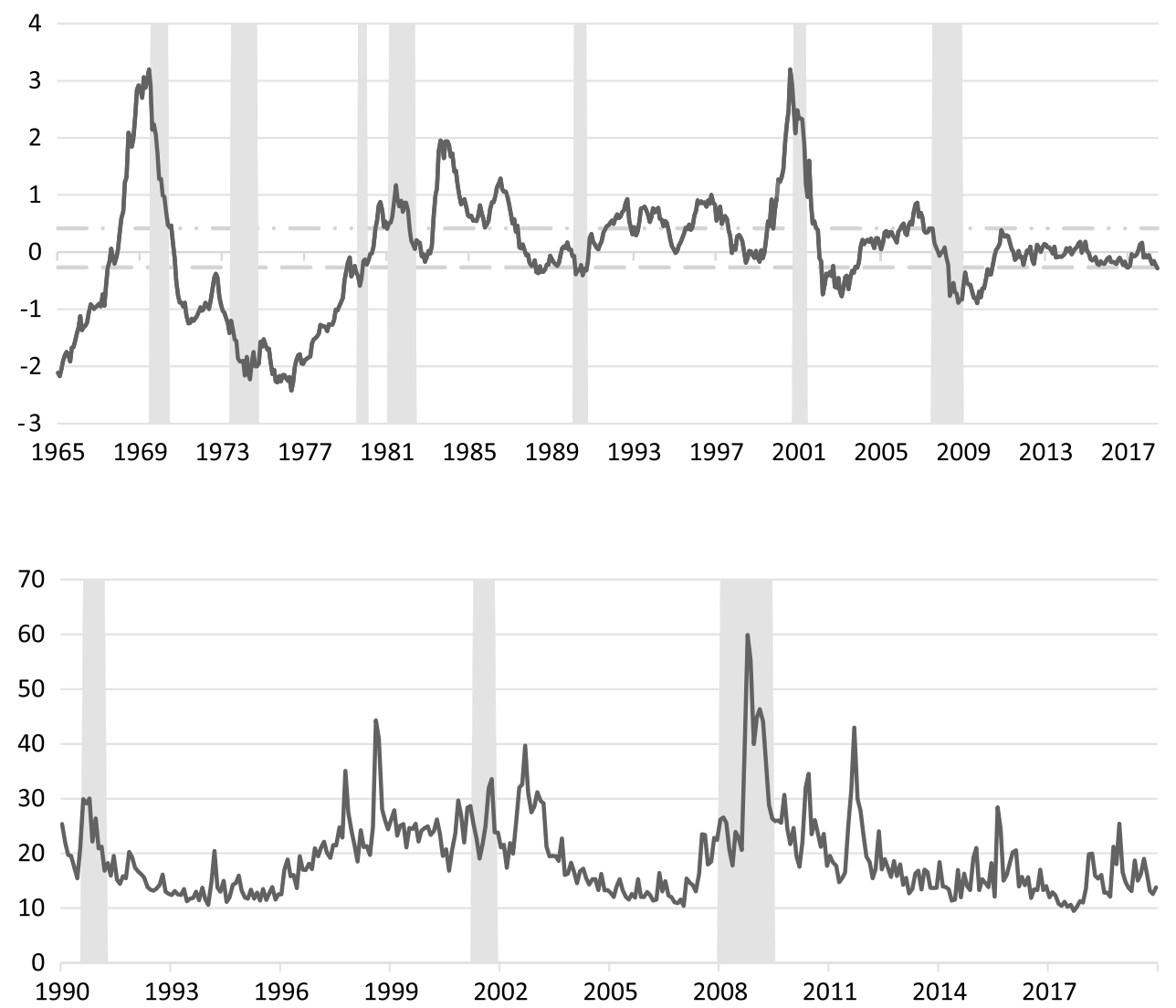

Fig. 2 Month-end values of VIX from January 1990 to December 2019
Figure 2 plots the end-of-month values of the VIX from January 1990 to December 2019 along with the NBER recession periods. 2006). Moreover, data for the volatility index (VIX) are available for the January 1990 to December 2019 period from the CBOE. The VIX measures the 30-day option implied volatility of the S\&P 500 index, with expected volatility in annualized percentage form (CBOE, 2019). 
Table 3 Factor returns conditional on prior 12- and 1-month returns

\begin{tabular}{|c|c|c|c|c|c|c|c|c|}
\hline \multirow[t]{3}{*}{ Factor } & \multicolumn{4}{|c|}{ Conditional on prior 12 -month return (1) } & \multicolumn{4}{|c|}{ Conditional on prior 1-month return (2) } \\
\hline & \multicolumn{2}{|l|}{ Intercept } & \multicolumn{2}{|l|}{ Slope } & \multicolumn{2}{|l|}{ Intercept } & \multicolumn{2}{|l|}{ Slope } \\
\hline & $\widehat{\alpha}$ & $t(\widehat{a})$ & $\widehat{\beta}$ & $t(\hat{\beta})$ & $\widehat{\alpha}$ & $t(\widehat{a})$ & $\widehat{\beta}$ & $t(\hat{\beta})$ \\
\hline Average & 0.10 & $(0.75)$ & 0.33 & $(2.26)$ & 0.17 & $(1.92)$ & 0.32 & (2.83) \\
\hline ASSETG & 0.12 & $(0.99)$ & 0.25 & $(1.56)$ & -0.01 & $(-0.10)$ & 0.55 & $(3.60)$ \\
\hline $\mathrm{BAB}$ & -0.22 & $(-0.63)$ & 1.32 & $(3.53)$ & 0.14 & $(0.67)$ & 1.03 & (3.95) \\
\hline $\mathrm{BM}$ & 0.05 & $(0.27)$ & 0.39 & $(1.70)$ & -0.10 & $(-0.61)$ & 0.75 & $(3.48)$ \\
\hline CFP & 0.13 & $(0.78)$ & 0.24 & (1.17) & -0.03 & $(-0.21)$ & 0.57 & (2.96) \\
\hline DP & 0.00 & $(-0.05)$ & 0.00 & $(0.11)$ & -0.44 & $(-2.95)$ & 0.91 & (4.27) \\
\hline $\mathrm{EP}$ & 0.10 & $(0.63)$ & 0.30 & $(1.45)$ & -0.08 & $(-0.55)$ & 0.68 & (3.48) \\
\hline $\mathrm{HML}_{\mathrm{D}}$ & -0.17 & $(-0.68)$ & 0.73 & $(2.53)$ & -0.25 & $(-1.36)$ & 1.01 & (3.92) \\
\hline $\mathrm{OP}$ & 0.03 & $(0.19)$ & 0.35 & $(1.71)$ & -0.09 & $(-0.69)$ & 0.62 & (3.74) \\
\hline QMJ & 0.09 & $(0.65)$ & 0.43 & $(2.51)$ & 0.01 & $(0.05)$ & 0.68 & (3.95) \\
\hline STR & 0.49 & (1.43) & 0.01 & $(0.03)$ & 0.56 & $(3.10)$ & -0.11 & $(-0.45)$ \\
\hline UMD & 0.72 & $(2.70)$ & -0.10 & $(-0.29)$ & 0.38 & (1.44) & 0.43 & (1.28) \\
\hline
\end{tabular}

\section{Empirical findings}

\section{Testing for autocorrelation}

Following Ehsani and Linnainmaa (2019), we begin our empirical analysis by testing whether past factor returns have predictive power on future returns. To do so, we regress the monthly factor returns conditional on their past 1- and 12-month return as follows:

$R_{i, t}=\alpha_{i}+\beta_{i} D_{i, 12}$,

and

$R_{i, t}=\alpha_{i}+\beta_{i} D_{i, 1}$

where $R_{i, t}$ denotes the return to factor $i$ in month $t$, and $D_{i, 12}$ is a dummy variable equal to one when the factor $i$ 's average return from month $t-12$ to $t-1$ is positive and zero otherwise. The dummy variable $D_{i, 1}$ equals one when factor $i$ 's return in the prior month is positive and zero otherwise. The intercept term $\alpha_{i}$ in Eq. (1) captures the average returns after the prior 12-month return is negative, and the slope coefficient $\beta_{i}$ measures the difference in average returns after positive and negative prior 12-month returns. Further, the intercept term $\alpha_{i}$ in Eq. (2) captures the average returns after the prior 1-month return is negative, and the slope coefficient $\beta_{i}$ measures the difference in average returns after positive and negative prior 1-month returns.

OLS regression estimates for each factor conditional on factor $i$ 's prior 12- and 1-month returns are shown in Table 3. On average, the factors earn positive returns after 12 months of underperformance. The average return to the UMD is significantly positive following periods of negative 12-month returns $(0.72 \%)$ and higher than the average return after a positive 12 -month performance $(0.62 \%)$. The equalweighted portfolio that invests in all factors earns an average return of $0.10 \%$ in the month following a negative 12-month period and $0.43 \%$ after a positive 12 -month period. Overall, the regression results suggest that factor returns are highly persistent, and on average higher following periods of positive returns than after negative-return periods.

\section{Factor momentum portfolios}

The factor momentum portfolios are formed using $L$-month lagged factor returns and held for $H$ months, with each portfolio denoted as a $L-H$ pair. We test the performance of cross-sectional (CS) 1-1, 6-1, 6-6, 11-1, and 12-1 strategies and time-series (TS) 1-1, 6-1, and 12-1 strategies. Both CS and TS strategies are rebalanced monthly at the end of the formation period. The CS factor momentum portfolios are long two factors with the highest formation period returns and short two factors with the lowest formation period returns. Taking a long (short) position in two factors follows the allocation ratio of Arnott et al (2018) using 11 total factors. ${ }^{13}$ In contrast, the CS factor momentum strategies of Ehsani and Linnainmaa (2019) and Gupta and Kelly (2019) are long factors with above-median returns and short factors with below-median returns. Our choice to follow the former study's approach has two important implications: (1) it provides an opportunity to re-assess the relevance of recent stylized facts of factor momentum documented in Ehsani and Linnainmaa (2019) and Gupta and Kelly (2019), and (2)

\footnotetext{
13 As in their study, the number of long and short factors is calculated as a ratio of the total number of factors as $\max \left\{\operatorname{round}\left(\frac{3}{20} \times 11\right), 1\right\}=2$.
} 
it meets the requirements of scientific replications as detailed in Hou et al (2020, p.4).

Specifically, the CS 12-1 strategy is formed based on the average factor returns from month $t-12$ to $t-1$, whereas the CS 11-1 is formed using the average factor returns from $t-12$ to $t-2$ and skipping the month $t-1$ before the holding month $t$. Further, the CS 11-1 strategy is included to test how the performance is affected by skipping a month before the holding period. The return to each long (short) portfolio in month $t$ is calculated as the equal-weighted average return of the two factors with the highest (lowest) formation period returns. Since the CS 6-6 strategy includes overlapping holding periods, we follow the methodology of Jegadeesh and Titman (1993) and calculate the strategy's long and short returns with $1 / 6$ th weight in each portfolio formed at times $t-6$ to $t-1$. The returns to CS factor momentum strategies are calculated as the spreads between long and short portfolios. TS factor momentum strategies are long factors with positive formation period returns and short factors with negative formation period returns. ${ }^{14}$

Both CS and TS factor momentum strategies are longshort portfolios. According to Ehsani and Linnainmaa (2019), the factor momentum strategy can be interpreted as a strategy that bets on (against) the factors when they have relatively high (low) or positive (negative) prior returns. For consistency, we refer to long (short)-side portfolios as the winner (loser)-factor portfolios and report the returns of the factor momentum portfolio as the spreads between the winner- and loser-factor portfolios. Table 4 presents the summary statistics for CS and TS factor momentum strategies. Strikingly, all long-short factor momentum portfolios have positive and statistically significant average returns. The CS 1-1 strategy has the highest monthly average return of $1.00 \%$, which is higher than for any of the 11 individual factors. It is also the only strategy that has negative (albeit insignificant) short-side returns. Consistent with the results of previous studies on factor momentum, both CS and TS strategies have the best performance with the 1-month formation and holding periods. Contrary to the findings of Gupta and Kelly (2019) and Ehsani and Linnainmaa (2019), the CS strategies have higher average returns than the TS strategies for equal formation periods. This difference is likely explained by the fact that the CS portfolios of Gupta and Kelly (2019) and Ehsani and Linnainmaa (2019) are long factors with above-median returns and short factors

\footnotetext{
$\overline{14}$ Because the number of factors in long and short portfolios varies from month to month, using equal-weighted average returns is equivalent to a zero-investment strategy that always has an equally large position in long and short portfolios. For example, if the time-series factor momentum strategy is long ten factors and short one factor, the weight on each long factor corresponds to $1 / 10$ of the weight on the short position.
}

with below-median returns, whereas our CS portfolios are formed in line with Arnott et al's (2018) approach. Furthermore, another interesting result from Panel A of Table 4 is that, for five-out-of-eight factor momentum strategies, the short-legs are statistically insignificant, implying that those strategies are mainly driven by the long-leg. This is an important issue which will be further discussed in the forthcoming "Practical implications" section.

TS factor momentum strategies have lower volatilities due to being more diversified than the CS portfolios. The TS 1-1, 6-1, and 12-1 portfolios are on average long 6.1, 6.9, and 7.3 factors and short 4.9, 4.1, and 3.7 factors, respectively. The CS portfolios are by construction always long and short two factors. The annualized standard deviations of factor momentum strategies vary between 10.15 and $21.89 \%$ and annualized returns between 4.03 and $12.67 \%$. Moreover, the performance of the CS 11-1 strategy is similar to CS 12-1, but the summary statistics show that skipping a month before the holding period does not increase the performance of factor momentum.

Panel C of Table 4 shows that the CS 1-1 and TS 6-1 strategies have positively skewed return distributions, whereas other strategies are negatively skewed. Interestingly, none of the factor momentum strategies has a higher left tail risk than the UMD factor, which has a skewness of - 1.3, and only the CS 6-6 strategy has a worse one-month return than the UMD factor. These findings suggest that, even though factor momentum strategies suffer crash risks, they are not as severe as those associated with the individual stock price momentum strategy. Both CS strategies that are formed on 6-month lagged returns have similar long-short returns, but the returns of winner and loser portfolios show notable differences. While the CS 6-6 winner portfolio has the highest average returns, the strategy's long-short returns are decreased by the returns of the loser-factor portfolio.

Panel A of Table 5 reports the pairwise correlation coefficients between the returns of factor momentum strategies. To conserve space, the CS 11-1 strategy is henceforth omitted, as its performance is similar to the CS 12-1 strategy. The returns to TS and CS strategies with equal formation periods are highly correlated even though the time-series portfolios are more diversified than the cross-sectional portfolios. Panel B reports the return correlations between factor momentum strategies and UMD factor as well as factor momentum strategies and STR factor. All factor momentum strategies are negatively correlated with the STR factor, and strategies with shorter formation periods are more negatively correlated with STR than strategies with longer formation periods. Notably, the correlations between the UMD factor and factor momentum strategies are positive and linearly increasing with the length of the formation period. ${ }^{15}$ Next, to illustrate the performance of the

\footnotetext{
${ }^{15}$ In unreported results, we estimate the relative factor weights for 1-1 and 6-1 portfolios also. Results are available upon request from the authors.
} 
Table 4 Summary statistics for factor momentum portfolios

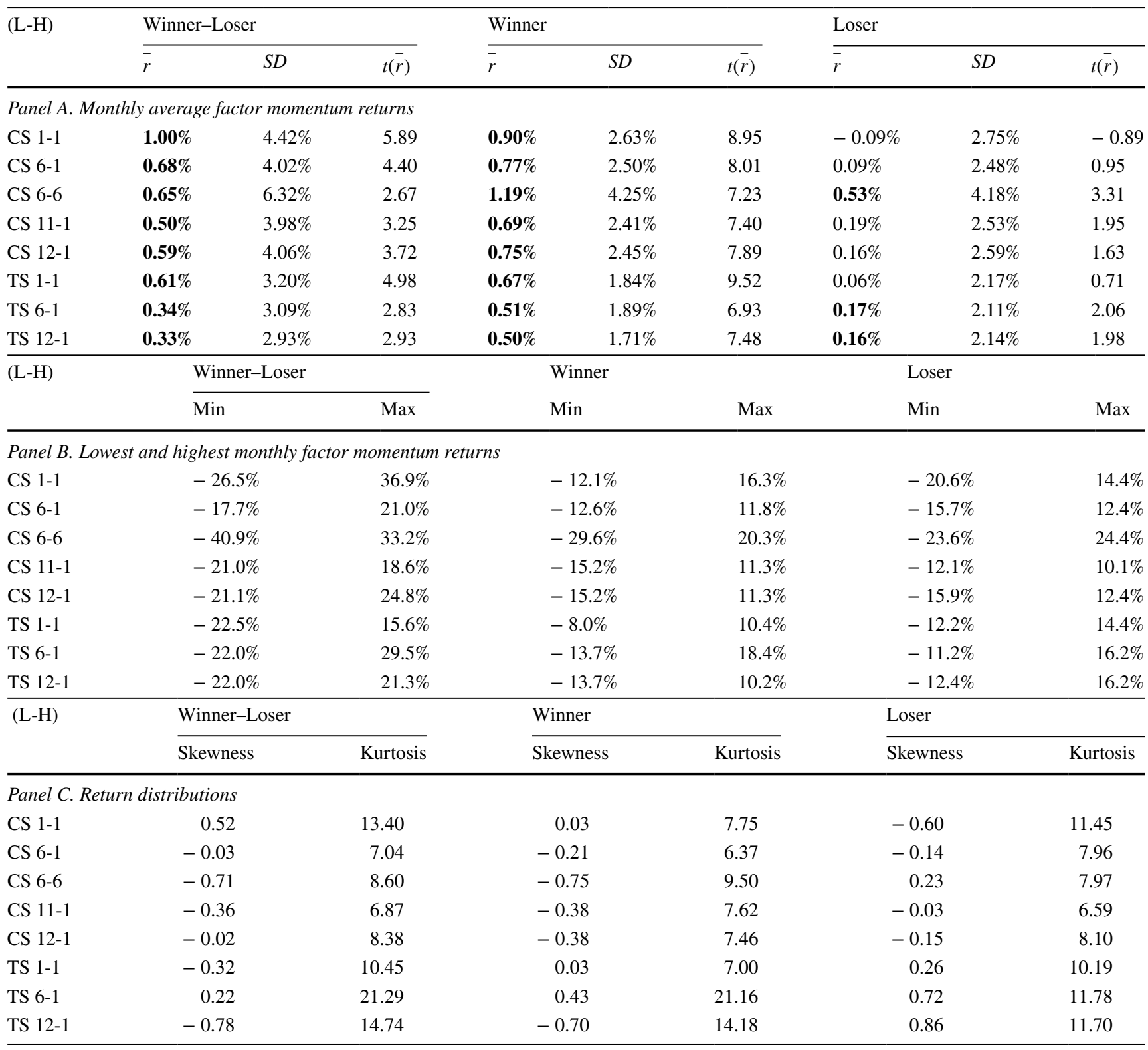

Bold values denote statistical significance at the $5 \%$ level

factor momentum strategies and UMD factor over time, Figs. 3 and 4 plot the cumulative returns of $\$ 1$ invested. ${ }^{16}$ The cumulative returns of the CS 1-1 strategy are superior to any other strategy. When the monthly volatilities are scaled to match the volatility of the UMD factor, CS 1-1, TS 1-1, and CS 6-1 clearly outperform the UMD factor.

\footnotetext{
${ }^{16}$ Figure 3 plots the cumulative raw returns, and Fig. 4 the cumulative returns of portfolios that are scaled to have monthly volatility of the UMD factor. The Y-axis in both figures is in logarithmic form.
}

\section{Risk-adjusting factor momentum portfolios}

Are the payoffs of factor momentum strategies explained by their exposures to systematic risks? Table 6 reports regression model results for the long-short factor momentum strategies with respect to the Fama and French (2018) six-factor model (FF6). Regressing factor momentum returns on the FF6 model lowers the alphas of all factor momentum strategies, and four of the strategies lose statistical significance. Confirming evidence in Arnott et al (2018), the FF6 does little to explain the returns of the CS 1-1 and TS 1-1 strategies. The annualized alphas for the CS $1-1$ and TS $1-1$ strategies are $10.23 \%$ and $6.08 \%$, 
Table 5 Correlations of factor momentum returns

$\begin{array}{lllllll}\text { CS } 1-1 & \text { TS } 1-1 & \text { CS 6-1 } & \text { CS 6-6 } & \text { TS 6-1 } & \text { CS 12-1 } & \text { TS 12-1 }\end{array}$

Panel A. Correlations between factor momentum strategies

\begin{tabular}{|c|c|c|c|c|c|c|c|}
\hline CS 1-1 & 1.00 & & & & & & \\
\hline TS $1-1$ & 0.90 & 1.00 & & & & & \\
\hline CS 6-1 & 0.41 & 0.38 & 1.00 & & & & \\
\hline CS 6-6 & 0.15 & 0.10 & 0.76 & 1.00 & & & \\
\hline TS 6-1 & 0.30 & 0.34 & 0.79 & 0.65 & 1.00 & & \\
\hline CS 12-1 & 0.28 & 0.25 & 0.72 & 0.82 & 0.70 & 1.00 & \\
\hline \multirow[t]{2}{*}{ TS $12-1$} & 0.27 & 0.29 & 0.62 & 0.71 & 0.84 & 0.84 & 1.00 \\
\hline & CS 1-1 & TS 1-1 & CS 6-1 & CS 6-6 & TS 6-1 & CS 12-1 & TS 12-1 \\
\hline \multicolumn{8}{|c|}{ Panel B. Correlations between factor momentum strategies and the UMD and STR factors } \\
\hline UMD & 0.10 & 0.12 & 0.46 & 0.58 & 0.53 & 0.68 & 0.66 \\
\hline STR & -0.69 & -0.67 & -0.42 & -0.19 & -0.40 & -0.32 & -0.32 \\
\hline
\end{tabular}

Fig. 3 Cumulative factor momentum returns from July 1964 to December 2019
1000

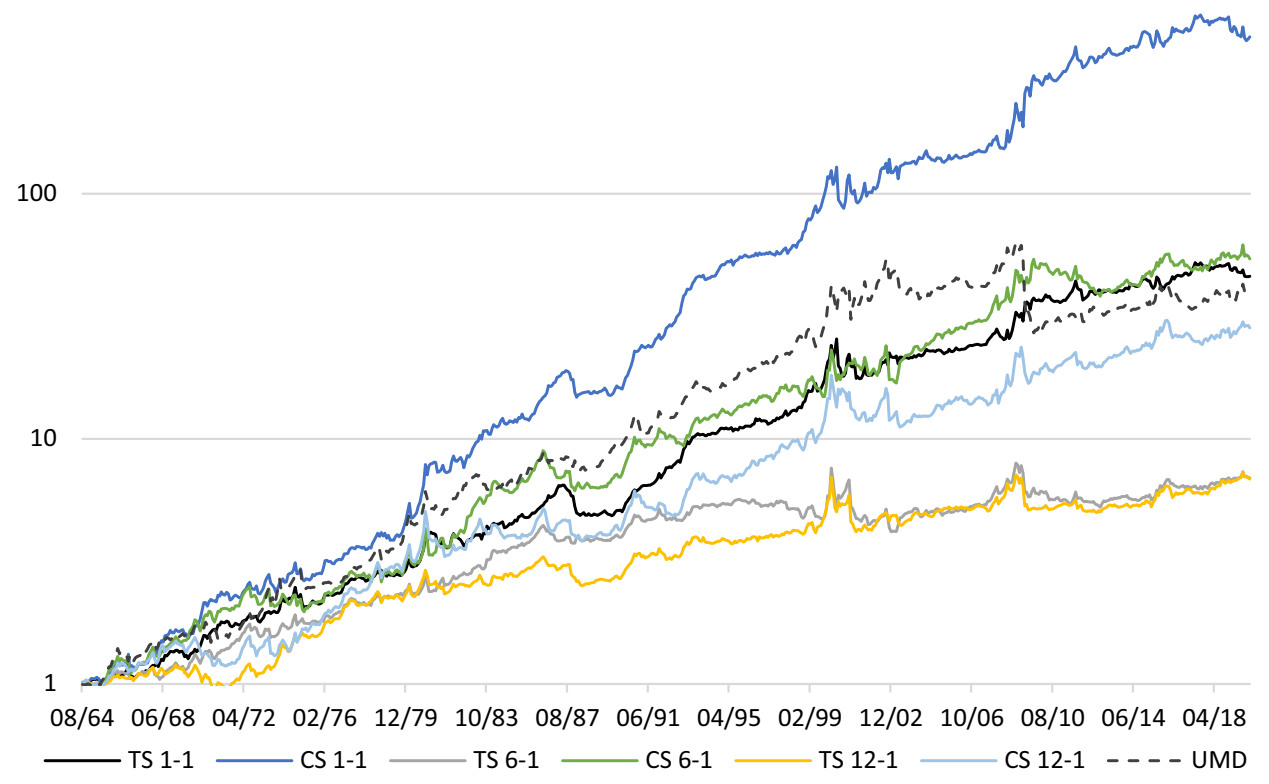

respectively. Furthermore, the CS 1-1 and TS 1-1 strategies have significantly positive exposure to the investment factor (CMA), which implies that these strategies are exposed to companies that exhibit low asset growths. All CS and TS strategies with matching formation periods have similar factor loadings, but the coefficients across different formation periods show substantial variation. These findings suggest that each formation period captures different types of mispricing due to different trading factors.

\section{Risk-managing factor momentum portfolios}

Figures 3 and 4 show that factor momentum strategies are not similarly prone to crashes like the UMD factor. For example, the UMD factor lost $49.09 \%$ of its cumulative value from March 2009 to May 2009, whereas the CS 1-1 and TS $1-1$ strategies gained $26.39 \%$ and $11.35 \%$, respectively. Nevertheless, summary statistics in Table 4 show that factor momentum portfolios experienced significant drawdowns. Unlike Moreira and Muir (2017), who scaled 
Fig. 4 Cumulative factor momentum returns from July 1964 to December 2019 (scaled)
1000

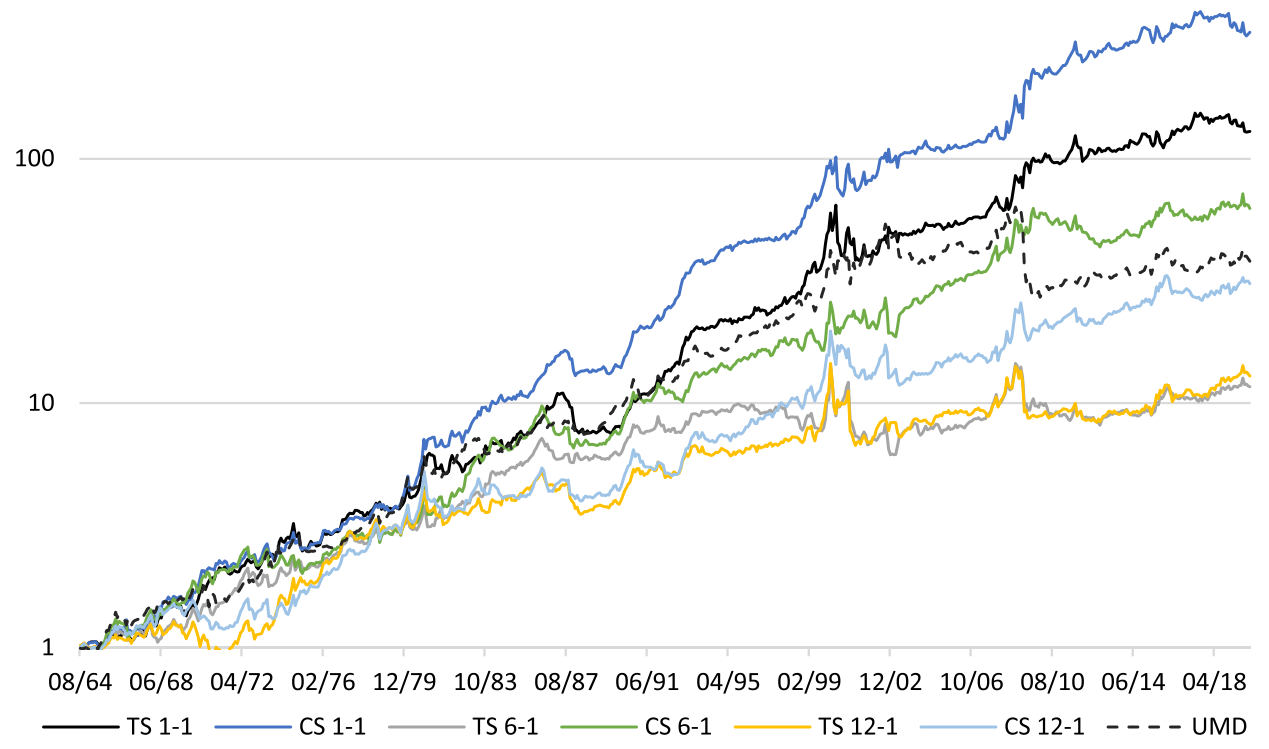

Table 6 FF6 model regressions for factor momentum portfolios

\begin{tabular}{llllllll}
\hline & CS 1-1 & TS 1-1 & CS 6-1 & TS 6-1 & CS 12-1 & TS 12-1 & CS 6-6 \\
\hline Alpha & $\mathbf{0 . 8 1 5}$ & $\mathbf{0 . 4 9 3}$ & $\mathbf{0 . 4 3 6}$ & 0.150 & 0.176 & 0.038 & 0.094 \\
& $(4.33)$ & $(3.40)$ & $(2.68)$ & $(1.23)$ & $(1.42)$ & $(0.41)$ & $(0.38)$ \\
MKT-RF & -0.033 & -0.058 & -0.003 & -0.043 & 0.035 & 0.015 & 0.060 \\
& $(-0.55)$ & $(-1.35)$ & $(-0.05)$ & $(-1.09)$ & $(0.76)$ & $(0.45)$ & $(0.72)$ \\
SMB & 0.022 & 0.031 & $\mathbf{0 . 1 2 1}$ & 0.092 & $\mathbf{0 . 2 1 7}$ & $\mathbf{0 . 1 2 9}$ & $\mathbf{0 . 3 4 3}$ \\
& $(0.28)$ & $(0.52)$ & $(2.03)$ & $(1.45)$ & $(3.90)$ & $(2.52)$ & $(4.11)$ \\
HML & -0.124 & -0.087 & 0.028 & -0.011 & -0.031 & -0.052 & 0.138 \\
& $(-1.16)$ & $(-1.02)$ & $(0.25)$ & $(-0.13)$ & $(-0.30)$ & $(-0.71)$ & $(0.74)$ \\
RMW & 0.147 & 0.025 & -0.209 & $-\mathbf{0 . 2 9 9}$ & -0.154 & -0.161 & -0.164 \\
& $(0.88)$ & $(0.19)$ & $(-1.70)$ & $(-1.96)$ & $(-1.75)$ & $(-1.77)$ & $(-0.96)$ \\
CMA & $\mathbf{0 . 5 2 0}$ & $\mathbf{0 . 4 1 2}$ & -0.110 & 0.043 & -0.151 & 0.064 & $-\mathbf{0 . 4 9 8}$ \\
& $(3.48)$ & $(3.70)$ & $(-0.75)$ & $(0.35)$ & $(-1.45)$ & $(0.78)$ & $(-2.04)$ \\
UMD & 0.082 & 0.080 & $\mathbf{0 . 4 5 8}$ & $\mathbf{0 . 4 0 2}$ & $\mathbf{0 . 6 7 2}$ & $\mathbf{0 . 4 6 3}$ & $\mathbf{0 . 9 0 8}$ \\
& $(0.59)$ & $(0.94)$ & $(5.23)$ & $(7.56)$ & $(12.01)$ & $(13.88)$ & $(7.42)$ \\
Adjusted $\mathrm{R}^{2}$ & 0.045 & 0.069 & 0.236 & 0.336 & 0.526 & 0.473 & 0.392 \\
\hline
\end{tabular}

Bold figures denote statistical significance at the 5\% level. Corresponding $t$-statistics are shown in parentheses.
UMD returns by the inverse of the previous month's realized variance, we use the 1-month lagged month-end value of VIX as a proxy for expected market volatility. There are a number of advantages of using an option-implied measure for expected market volatility: (1) Barroso and Santa-Clara (2015) and Moreira and Muir (2017) found that using market return volatility (instead of factor-specific volatility) produced virtually the same results; (2) a naïve investor can readily access VIX data at no cost (rather than substantial data collection costs for multiple realized factor volatilities (McAleer and Medeiros, 2008); and (3) implied volatility outperforms realized volatility in forecasting future volatility (Christensen and Prabhala, 1998; Whaley, 2009).
Option-implied volatility-managed portfolios were constructed by scaling a factor momentum strategy's excess return by the inverse of the previous month's conditional VIX. Each month the volatility-managed strategy increases or decreases risk exposure to the portfolio according to variation in the conditional VIX. The option-implied volatility-managed factor momentum portfolio denoted as $F M O M_{i, t}^{\sigma}$ is defined as:

$F M O M_{i, t}^{\sigma}=\frac{c}{E_{t}\left[V L_{t-1}^{M k t}\right]}=\frac{c}{V I X_{t-1}} F_{M O M_{i, t}}=s_{t} F^{M O M_{i, t}}$,

where $c$ is a constant scaling factor corresponding to the target level volatility, $E_{t}\left[V O L_{t-1}^{M k t}\right]$ is the expected volatility of 
Table 7 Summary statistics for risk-managed factor momentum portfolios

\begin{tabular}{|c|c|c|c|c|c|c|c|}
\hline & CS $1-1$ & CS 6-1 & CS 6-6 & CS $12-1$ & TS $1-1$ & TS 6-1 & TS $12-1$ \\
\hline \multicolumn{8}{|c|}{ Panel A. Unscaled factor momentum } \\
\hline Mean $(\%)$ & $\begin{array}{l}\mathbf{1 . 0 5} \\
(3.96)\end{array}$ & $\begin{array}{l}\mathbf{0 . 6 6} \\
(2.98)\end{array}$ & $\begin{array}{l}0.60 \\
(1.74)\end{array}$ & $\begin{array}{l}\mathbf{0 . 6 2} \\
(2.74)\end{array}$ & $\begin{array}{l}\mathbf{0 . 6 8} \\
(3.60)\end{array}$ & $\begin{array}{l}0.22 \\
(1.15)\end{array}$ & $\begin{array}{l}0.31 \\
(1.83)\end{array}$ \\
\hline Maximum (\%) & 36.91 & 20.92 & 33.17 & 24.82 & 15.56 & 29.52 & 21.28 \\
\hline Minimum & $-26.51 \%$ & $-17.75 \%$ & $-40.90 \%$ & $-21.06 \%$ & $-22.46 \%$ & $-21.98 \%$ & $-21.98 \%$ \\
\hline Volatility & $5.01 \%$ & $4.18 \%$ & $6.57 \%$ & $4.30 \%$ & $3.58 \%$ & $3.56 \%$ & $3.24 \%$ \\
\hline Skewness & 0.64 & 0.25 & -0.43 & 0.10 & -0.42 & 0.48 & -0.84 \\
\hline \multirow[t]{2}{*}{ Kurtosis } & 13.61 & 6.63 & 9.91 & 8.71 & 10.73 & 21.78 & 17.03 \\
\hline & CS $1-1 *$ & CS $6-1 *$ & CS 6-6* & CS $12-1 *$ & TS $1-1 *$ & TS 6-1* & TS $12-1 *$ \\
\hline \multicolumn{8}{|c|}{ Panel B. Scaled factor momentum, annualized target volatility $20 \%$} \\
\hline Mean $(\%)$ & $\begin{array}{l}\mathbf{1 . 1 7} \\
(4.92)\end{array}$ & $\begin{array}{l}\mathbf{0 . 7 8} \\
(3.75)\end{array}$ & $\begin{array}{l}\mathbf{0 . 7 5} \\
(2.22)\end{array}$ & $\begin{array}{l}\mathbf{0 . 7 8} \\
(3.68)\end{array}$ & $\begin{array}{l}\mathbf{0 . 7 6} \\
(4.38)\end{array}$ & $\begin{array}{l}\mathbf{0 . 3 3} \\
(2.01)\end{array}$ & $\begin{array}{l}\mathbf{0 . 4 1} \\
(2.63)\end{array}$ \\
\hline Maximum (\%) & 18.32 & 16.77 & 28.05 & 19.90 & 12.41 & 23.67 & 17.06 \\
\hline Minimum (\%) & -22.42 & -11.40 & -26.27 & -13.53 & -18.99 & -16.38 & -16.38 \\
\hline Volatility (\%) & 4.50 & 3.93 & 6.42 & 4.03 & 3.30 & 3.07 & 2.97 \\
\hline Skewness & -0.04 & 0.28 & -0.04 & 0.24 & -0.33 & 0.70 & -0.18 \\
\hline Kurtosis & 6.32 & 4.22 & 5.55 & 5.11 & 7.51 & 14.91 & 9.60 \\
\hline
\end{tabular}

Bold values denote statistical significance at the $5 \%$ level. Corresponding $t$-statistics are shown in parentheses. Asterisks denote risk-managed factor momentum strategies.

Fig. 5 Cumulative returns of scaled 1-1 factor momentum

100 portfolios.

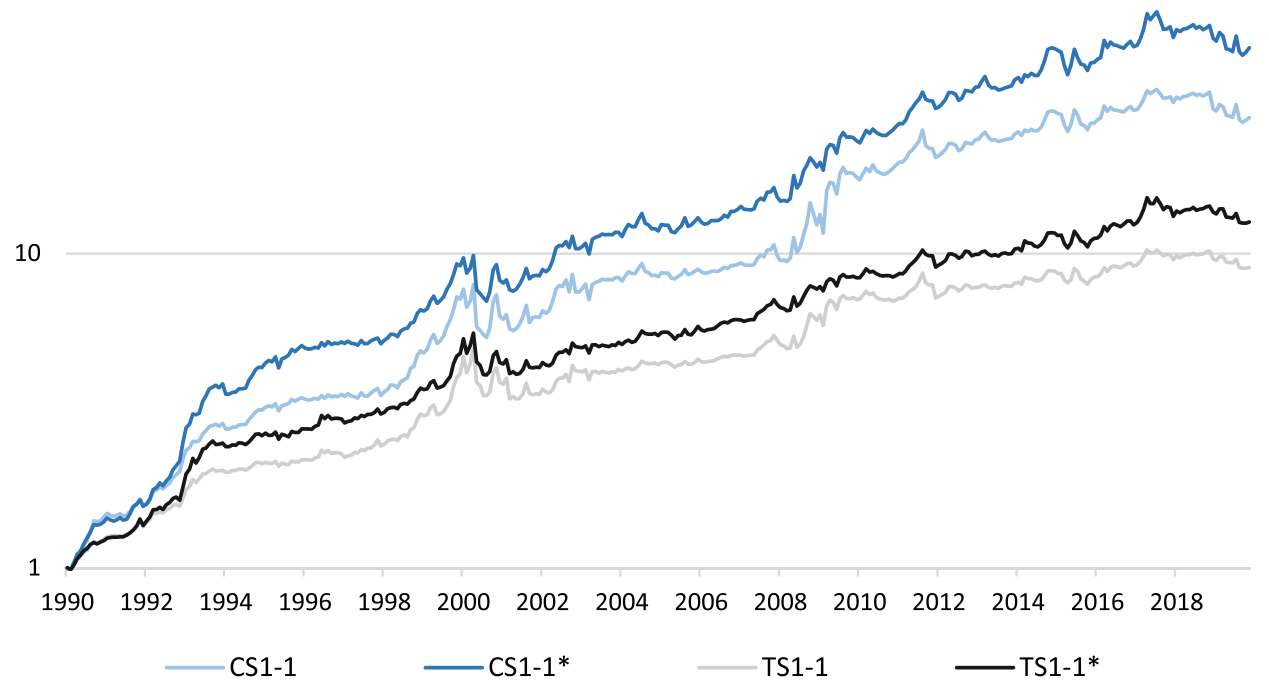

the stock market conditional on time $t-1, F M O M_{i, t}$ is the payoff of factor momentum strategy $i$ in month $t$, and $V I X_{t-1}$ is the 1-month lagged month-end value of VIX. ${ }^{17}$

We use a target annualized volatility of $c=20 \%$, which is close to the long-term average of VIX, to calculate the

17 Note that Barroso and Santa-Clara's (2015), and Moreira and Muir's (2017) approach does actually not account for an expectation because they set a past value of realized volatility equal to the expectation, whereas our approach incorporates the market expectation congruent with the time period of the corresponding payoff. portfolio weights for each month. ${ }^{18}$ The scaling factor varies between 0.33 and 2.10, with an average of $1.17 .{ }^{19}$ Panels A and B of Table 7 report the summary statistics for

18 The choice of $c$ is arbitrary and has no effect on the strategy's Sharpe ratio (Moreira and Muir, 2017, p. 1616).

19 The time series evolution of the scaling factor is virtually the same as documented in Barroso and Santa-Clara (2015) who reported 
Table 8 Risk-adjusting risk-managed factor momentum

\begin{tabular}{|c|c|c|c|c|c|c|c|}
\hline & CS $1-1 *$ & CS 6-1* & CS 6-6* & CS $12-1 *$ & TS $1-1 *$ & TS 6-1* & TS $12-1 *$ \\
\hline \multicolumn{8}{|c|}{ Panel A: Alpha against corresponding unscaled factor momentum portfolio } \\
\hline \multirow[t]{2}{*}{ Alpha } & $\begin{array}{l}\mathbf{0 . 2 9 9} \\
(3.38)\end{array}$ & $\begin{array}{l}\mathbf{0 . 1 9 7} \\
(3.12)\end{array}$ & $\begin{array}{l}0.198 \\
(1.66)\end{array}$ & $\begin{array}{l}\mathbf{0 . 2 3 8} \\
(2.97)\end{array}$ & $\begin{array}{l}\mathbf{0 . 1 7 2} \\
(3.61)\end{array}$ & $\begin{array}{l}\mathbf{0 . 1 4 9} \\
(3.13)\end{array}$ & $\begin{array}{l}\mathbf{0 . 1 4 3} \\
(2.55)\end{array}$ \\
\hline & CS $1-1^{*}$ & CS 6-1* & CS 6-6* & CS $12-1 *$ & TS $1-1^{*}$ & TS 6-1* & TS $12-1 *$ \\
\hline \multicolumn{8}{|c|}{ Panel B: Alpha against FF6 model } \\
\hline Alpha & $\begin{array}{l}\mathbf{0 . 3 2 4} \\
(2.85)\end{array}$ & $\begin{array}{l}\mathbf{0 . 1 9 0} \\
(2.69)\end{array}$ & $\begin{array}{l}0.146 \\
(1.19)\end{array}$ & $\begin{array}{l}\mathbf{0 . 1 9 7} \\
(2.28)\end{array}$ & $\begin{array}{l}\mathbf{0 . 1 8 0} \\
(2.87)\end{array}$ & $\begin{array}{l}\mathbf{0 . 1 4 7} \\
(2.85)\end{array}$ & $\begin{array}{l}\mathbf{0 . 1 2 2} \\
(2.01)\end{array}$ \\
\hline
\end{tabular}

Bold values denote statistical significance at the $5 \%$ level. Corresponding $t$-statistics are shown in parentheses. Asterisks denote risk-managed factor momentum strategies

the unscaled $\left(F M O M_{i}\right)$ and scaled factor momentum portfolios $\left(F M O M_{i}^{\sigma}\right)$, respectively. The data for VIX are available from January 1990 onwards; hence, the analysis period spans from February 1990 to December 2019. Overall, our results confirm Barroso and Santa-Clara (2015) and Moreira and Muir (2017)—namely, risk-managed factor momentum portfolios have higher average returns and lower monthly volatility than unscaled strategies. Furthermore, the average returns of scaled factor momentum portfolios are statistically significant with higher $t$-statistics than the unscaled portfolios. The risk-managed factor momentum portfolios have less negative 1-month returns than unscaled portfolios and lower kurtoses.

Figure 5 plots the cumulative returns of $\$ 1$ invested in the unscaled and scaled CS 1-1 and TS 1-1 portfolios. ${ }^{20} \mathrm{We}$ see that the cumulative returns of both risk-managed portfolios exceed the unscaled returns. Both CS 1-1 and TS 1-1 strategies have negative average returns in 2019 and weak performance in 2018. The low performance of these factor momentum portfolios stems from low factor returns, i.e., eight of the long-short factors have negative average returns in 2019, and eight of the factors have average returns that are below their long-term averages in 2018. Overall, our findings suggest that the performance of factor momentum is increased after volatility scaling, but the benefits are not as beneficial as in the case of stock price momentum portfolios (Daniel and Moskowitz, 2016).

Like Moreira and Muir (2017), we regress scaled factor momentum payoffs on unscaled factor momentum returns. Panel A of Table 8 presents the alphas for each risk-managed

\footnotetext{
Footnote 19 (continued)

weights varying between 0.13 and 2.00 with an average of 0.90 . Data are available upon request from the authors.

${ }^{20}$ Again, the Y-axis is in logarithmic form.
}

factor momentum portfolio compared to the corresponding unscaled factor momentum portfolio with equal formation and holding periods. As a robustness check, in the sample period from February 1990 to December 2019, we regress the risk-managed factor momentum returns on the FF6 model. Panel B of Table 8 shows that the FF6 factors have similar explanatory power with respect to risk-managed factor momentum returns as unscaled factor momentum returns in Panel A.

\section{Testing for optionality effects and exploring tail risks}

Following Daniel and Moskowitz (2016), we test whether factor momentum strategies are subject to similar crash risks as stock price momentum. Also, we test whether optionimplied volatility-management remedies crash risks. Using their methodology, we regress factor momentum returns on the following model:

$$
\begin{aligned}
R_{F M O M, t}= & \left(\alpha_{0}+\alpha_{\beta} \cdot I_{B, t-1}\right) \\
& +\left(\beta_{0}+I_{B, t-1}\left(\beta_{B}+I_{U, t} \cdot \beta_{B, U}\right)\right) R_{m, t}+\varepsilon_{t},
\end{aligned}
$$

where $I_{B, t-1}$ is an ex-ante bear market indicator variable, $I_{U, t}$ is a contemporaneous up-market indicator variable, and $R_{m, t}$ is the excess market return. In line with Daniel and Moskowitz (2016), the bear market indicator variable $\left(I_{B, t-1}\right)$ equals one when the 24-month cumulative excess market returns are negative and zero otherwise. The up-market indicator variable $\left(I_{U, t}\right)$ equals one when the excess market return at time $t$ is positive and zero otherwise.

Panels A and B in Table 9 report the optionality regressions for factor momentum portfolios and risk-managed factor momentum portfolios, respectively. The sample periods are July 1965 to December 2019 and February 1990 to December 2019. The $t$-statistics for regression coefficient estimates are reported in parentheses. As in Daniel and Moskowitz (2016), a significantly negative $\hat{\beta}_{B, U}$ coefficient implies option-like behavior in bear markets. Our results 
Table 9 Optionality of factor momentum portfolios

\begin{tabular}{|c|c|c|c|c|c|c|c|c|}
\hline $\mathrm{C}$ & Variable & CS $1-1$ & CS 6-1 & CS 6-6 & CS $12-1$ & TS $1-1$ & TS 6-1 & TS $12-1$ \\
\hline \multicolumn{9}{|c|}{ Panel A: Optionality of factor momentum portfolios } \\
\hline$\hat{\alpha}_{0}$ & 1 & $\begin{array}{l}\mathbf{1 . 0 9 2} \\
(5.43)\end{array}$ & $\begin{array}{l}\mathbf{0 . 6 3 2} \\
(3.51)\end{array}$ & $\begin{array}{l}0.540 \\
(1.93)\end{array}$ & $\begin{array}{l}\mathbf{0 . 5 6 2} \\
(3.14)\end{array}$ & $\begin{array}{l}\mathbf{0 . 7 3 6} \\
(5.08)\end{array}$ & $\begin{array}{l}\mathbf{0 . 4 1 2} \\
(2.96)\end{array}$ & $\begin{array}{l}\mathbf{0 . 3 5 4} \\
(2.70)\end{array}$ \\
\hline$\hat{\alpha}_{B}$ & $I_{B, t-1}$ & $\begin{array}{l}-0.736 \\
(-1.16)\end{array}$ & $\begin{array}{l}-0.033 \\
(-0.06)\end{array}$ & $\begin{array}{l}1.573 \\
(1.78)\end{array}$ & $\begin{array}{l}-0.199 \\
(-0.35)\end{array}$ & $\begin{array}{l}-0.494 \\
(-1.08)\end{array}$ & $\begin{array}{l}-0.062 \\
(-0.14)\end{array}$ & $\begin{array}{l}0.272 \\
(0.66)\end{array}$ \\
\hline$\hat{\beta}_{0}$ & $R_{m, t}$ & $\begin{array}{l}-0.046 \\
(-0.93)\end{array}$ & $\begin{array}{l}\mathbf{0 . 1 6 9} \\
(3.79)\end{array}$ & $\begin{array}{l}\mathbf{0 . 3 9 4} \\
(5.69)\end{array}$ & $\begin{array}{l}\mathbf{0 . 2 3 8} \\
(5.35)\end{array}$ & $\begin{array}{l}-0.063 \\
(-1.74)\end{array}$ & $\begin{array}{l}0.058 \\
(1.67)\end{array}$ & $\begin{array}{l}\mathbf{0 . 1 0 8} \\
(3.33)\end{array}$ \\
\hline$\hat{\beta}_{B}$ & $I_{B, t-1} \cdot R_{m, t}$ & $\begin{array}{c}-\mathbf{0 . 3 7 4} \\
(-2.76)\end{array}$ & $\begin{array}{l}-\mathbf{0 . 4 9 9} \\
(-4.12)\end{array}$ & $\begin{array}{l}-\mathbf{0 . 4 9 1} \\
(-2.61)\end{array}$ & $\begin{array}{l}-\mathbf{0 . 5 6 3} \\
(-4.67)\end{array}$ & $\begin{array}{l}-\mathbf{0 . 2 3 4} \\
(-2.40)\end{array}$ & $\begin{array}{l}-\mathbf{0 . 2 5 3} \\
(-2.70)\end{array}$ & $\begin{array}{l}-\mathbf{0 . 2 2 0} \\
(-2.49)\end{array}$ \\
\hline$\hat{\beta}_{B, U}$ & $I_{B, t-1} \cdot I_{U, t} \cdot R_{m, t}$ & $\begin{array}{l}0.317 \\
(1.47)\end{array}$ & $\begin{array}{l}0.108 \\
(0.56)\end{array}$ & $\begin{array}{l}-\mathbf{0 . 5 9 5} \\
(-1.99)\end{array}$ & $\begin{array}{l}0.080 \\
(0.42)\end{array}$ & $\begin{array}{l}0.146 \\
(0.94)\end{array}$ & $\begin{array}{l}-0.060 \\
(-0.40)\end{array}$ & $\begin{array}{l}-0.157 \\
(-1.12)\end{array}$ \\
\hline Adjusted $R^{2}$ & & 0.025 & 0.051 & 0.076 & 0.074 & 0.037 & 0.041 & 0.046 \\
\hline $\mathrm{C}$ & Variable & CS $1-1 *$ & CS $6-1 *$ & CS 6-6* & CS $12-1 *$ & TS $1-1 *$ & TS $6-1 *$ & TS $12-1 *$ \\
\hline \multicolumn{9}{|c|}{ Panel B: Optionality of risk-managed factor momentum portfolios } \\
\hline$\hat{\alpha}_{0}$ & 1 & $\begin{array}{l}\mathbf{1 . 3 8 0} \\
(5.17)\end{array}$ & $\begin{array}{l}\mathbf{0 . 7 6 2} \\
(3.24)\end{array}$ & $\begin{array}{l}0.569 \\
(1.49)\end{array}$ & $\begin{array}{l}\mathbf{0 . 8 1 0} \\
(3.41)\end{array}$ & $\begin{array}{l}\mathbf{1 . 0 0 5} \\
(5.17)\end{array}$ & $\begin{array}{l}\mathbf{0 . 4 2 9} \\
(2.33)\end{array}$ & $\begin{array}{l}\mathbf{0 . 5 0 2} \\
(2.84)\end{array}$ \\
\hline$\hat{\alpha}_{B}$ & $I_{B, t-1}$ & $\begin{array}{l}-1.199 \\
(-1.16)\end{array}$ & $\begin{array}{l}-0.900 \\
(-0.99)\end{array}$ & $\begin{array}{l}1.150 \\
(0.78)\end{array}$ & $\begin{array}{l}-0.100 \\
(-0.11)\end{array}$ & $\begin{array}{l}-1.286 \\
(-1.71)\end{array}$ & $\begin{array}{l}-0.506 \\
(-0.71)\end{array}$ & $\begin{array}{l}-0.057 \\
(-0.08)\end{array}$ \\
\hline$\hat{\beta}_{0}$ & $R_{m, t}$ & $\begin{array}{l}-\mathbf{0 . 2 1 5} \\
(-3.05)\end{array}$ & $\begin{array}{l}0.067 \\
(1.08)\end{array}$ & $\begin{array}{l}\mathbf{0 . 2 7 4} \\
(2.72)\end{array}$ & $\begin{array}{l}0.100 \\
(1.60)\end{array}$ & $\begin{array}{l}-\mathbf{0 . 1 6 8} \\
(-3.27)\end{array}$ & $\begin{array}{l}0.018 \\
(0.37)\end{array}$ & $\begin{array}{l}0.030 \\
(0.65)\end{array}$ \\
\hline$\hat{\beta}_{B}$ & $I_{B, t-1} \cdot R_{m, t}$ & $\begin{array}{l}-0.058 \\
(-0.31)\end{array}$ & $\begin{array}{l}-\mathbf{0 . 3 7 3} \\
(-2.28)\end{array}$ & $\begin{array}{l}-0.305 \\
(-1.15)\end{array}$ & $\begin{array}{l}-0.312 \\
(-1.88)\end{array}$ & $\begin{array}{l}-0.081 \\
(-0.60)\end{array}$ & $\begin{array}{l}-0.121 \\
(-0.95)\end{array}$ & $\begin{array}{l}-0.083 \\
(-0.67)\end{array}$ \\
\hline$\hat{\beta}_{B, U}$ & $I_{B, t-1} \cdot I_{U, t} \cdot R_{m, t}$ & $\begin{array}{l}0.348 \\
(1.03)\end{array}$ & $\begin{array}{l}0.293 \\
(0.98)\end{array}$ & $\begin{array}{l}-0.497 \\
(-1.03)\end{array}$ & $\begin{array}{l}-0.184 \\
(-0.61)\end{array}$ & $\begin{array}{l}0.244 \\
(0.99)\end{array}$ & $\begin{array}{l}-0.053 \\
(-0.23)\end{array}$ & $\begin{array}{l}-0.227 \\
(-1.01)\end{array}$ \\
\hline Adjusted $R^{2}$ & & 0.002 & 0.009 & 0.022 & 0.035 & 0.037 & 0.007 & 0.016 \\
\hline
\end{tabular}

Bold values denote statistical significance at the $5 \%$ level. Corresponding $t$-statistics are shown in parentheses. Asterisks denote risk-managed factor momentum strategies

suggest that only the CS 6-6 factor momentum portfolio exhibits optionality effects because $\hat{\beta}_{B, U}$ is statistically significantly negative. Consistent with the previous findings in this study, the risk-managed factor momentum portfolios have higher alphas $\left(\hat{\alpha}_{0}\right)$ than plain factor momentum portfolios. ${ }^{21}$ Further, our result are similar to those documented in Grobys et al (2018) for industry-momentum portfolios. A possible explanation could be the similarities in return behavior between industry and factor momentum portfolios. In this regard, Arnott et al (2018) and Ehsani and Linnainmaa (2019) found that factor momentum portfolios subsume industry momentum. ${ }^{22}$

\footnotetext{
${ }^{21}$ Due to data availability, the sample period in Panel B is considerably shorter than in Panel A. The CS 6-1, 6-6, and 12-1 as well as TS 12-1 portfolios have significant exposure to market risk, and all factor momentum portfolios have negative market exposure during bear markets regardless of whether the contemporaneous market return is positive or negative. We observe that market risk exposures are partially removed by the volatility scaling in Panel B.

22 We also replicated Table 2 in Daniel and Moskowitz (2016) and added the corresponding payoffs of both scaled and unscaled CS and TS 1-1 strategies. In only one-third of the worst stock price momentum dates, the CS 1-1 factor momentum strategy generated lower
}

\section{Factor momentum and investor sentiment}

What are the underlying forces driving factor momentum? Stambaugh et al (2012) found that a long-short factor is on average more profitable during states of high investor sentiment because increased overpricing causes the shortside returns to be lower (or more profitable) than otherwise. Ehsani and Linnainmaa (2019) found that factor momentum returns are lower in high investor sentiment states because betting against loser factors becomes more expensive when

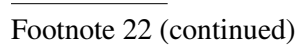

payoffs than the UMD factor, whereas the TS 1-1 factor momentum strategy always generated strictly higher payoffs. After risk-managing the factor momentum strategies, we observe that, in only one of the events, the CS 1-1 factor momentum strategy generated lower payoffs than the UMD factor, whereas the TS 1-1 factor momentum strategy improved even further. Overall, the tail risk of factor momentum is substantially lower than that of stock price momentum and generates average returns of similar economic magnitude. The corresponding table is available upon request from the authors. 
Table 10 Factor momentum returns conditional on investor sentiment

\begin{tabular}{|c|c|c|c|c|c|c|c|c|c|}
\hline & \multicolumn{3}{|l|}{ CS 1-1 } & \multicolumn{3}{|l|}{ CS 6-1 } & \multicolumn{3}{|l|}{ CS 6-6 } \\
\hline & FMOM & Winner & Loser & FMOM & Winner & Loser & FMOM & Winner & Loser \\
\hline HIGH & $\begin{array}{l}\mathbf{0 . 8 1 4} \\
(2.60)\end{array}$ & $\begin{array}{l}\mathbf{1 . 2 2 3} \\
(5.26)\end{array}$ & $\begin{array}{l}0.409 \\
(1.85)\end{array}$ & $\begin{array}{l}\mathbf{0 . 5 6 6} \\
(2.23)\end{array}$ & $\begin{array}{l}\mathbf{1 . 0 4 5} \\
(4.92)\end{array}$ & $\begin{array}{l}\mathbf{0 . 4 7 9} \\
(2.74)\end{array}$ & $\begin{array}{l}-0.060 \\
(-0.13)\end{array}$ & $\begin{array}{l}\mathbf{1 . 5 2 5} \\
(3.86)\end{array}$ & $\begin{array}{l}\mathbf{1 . 5 8 5} \\
(5.03)\end{array}$ \\
\hline MILD & $\begin{array}{l}\mathbf{1 . 4 4 4} \\
(5.05)\end{array}$ & $\begin{array}{l}\mathbf{0 . 9 5 9} \\
(7.22)\end{array}$ & $\begin{array}{l}-\mathbf{0 . 4 8 5} \\
(-2.51)\end{array}$ & $\begin{array}{l}\mathbf{1 . 0 9 5} \\
(4.44)\end{array}$ & $\begin{array}{l}\mathbf{0 . 8 7 0} \\
(5.55)\end{array}$ & $\begin{array}{l}-0.225 \\
(-1.59)\end{array}$ & $\begin{array}{l}\mathbf{1 . 3 9 6} \\
(3.46)\end{array}$ & $\begin{array}{l}\mathbf{1 . 2 7 5} \\
(4.61)\end{array}$ & $\begin{array}{l}-0.120 \\
(-0.45)\end{array}$ \\
\hline LOW & $\begin{array}{l}\mathbf{0 . 8 5 3} \\
(3.43)\end{array}$ & $\begin{array}{l}\mathbf{0 . 6 7 7} \\
(4.17)\end{array}$ & $\begin{array}{l}-0.175 \\
(-1.15)\end{array}$ & $\begin{array}{l}0.370 \\
(1.28)\end{array}$ & $\begin{array}{l}\mathbf{0 . 4 7 6} \\
(2.77)\end{array}$ & $\begin{array}{l}0.106 \\
(0.59)\end{array}$ & $\begin{array}{l}0.480 \\
(0.99)\end{array}$ & $\begin{array}{l}\mathbf{0 . 8 6 8} \\
(2.60)\end{array}$ & $\begin{array}{l}0.388 \\
(1.37)\end{array}$ \\
\hline \multirow[t]{3}{*}{ HIGH-LOW } & $\begin{array}{l}-0.039 \\
(-0.10)\end{array}$ & $\begin{array}{l}0.545 \\
(1.91)\end{array}$ & $\begin{array}{l}\mathbf{0 . 5 8 4} \\
(2.18)\end{array}$ & $\begin{array}{l}0.196 \\
(0.50)\end{array}$ & $\begin{array}{l}\mathbf{0 . 5 6 9} \\
(2.04)\end{array}$ & $\begin{array}{l}0.373 \\
(1.48)\end{array}$ & $\begin{array}{l}-0.540 \\
(-0.80)\end{array}$ & $\begin{array}{l}0.656 \\
(1.26)\end{array}$ & $\begin{array}{l}\mathbf{1 . 1 9 7} \\
(2.83)\end{array}$ \\
\hline & \multicolumn{3}{|l|}{ TS $1-1$} & \multicolumn{3}{|l|}{ TS 6-1 } & \multicolumn{3}{|l|}{ TS $12-1$} \\
\hline & FMOM & Winner & Loser & FMOM & Winner & Loser & FMOM & Winner & Loser \\
\hline $\mathrm{HIGH}$ & $\begin{array}{l}0.435 \\
(1.78)\end{array}$ & $\begin{array}{l}\mathbf{0 . 8 9 1} \\
(5.81)\end{array}$ & $\begin{array}{l}\mathbf{0 . 4 5 7} \\
(2.09)\end{array}$ & $\begin{array}{l}0.223 \\
(1.04)\end{array}$ & $\begin{array}{l}\mathbf{0 . 8 2 1} \\
(5.67)\end{array}$ & $\begin{array}{l}\mathbf{0 . 5 9 8} \\
(2.65)\end{array}$ & $\begin{array}{l}0.026 \\
(0.13)\end{array}$ & $\begin{array}{l}\mathbf{0 . 6 8 6} \\
(4.46)\end{array}$ & $\begin{array}{l}\mathbf{0 . 6 6 0} \\
(2.79)\end{array}$ \\
\hline MILD & $\begin{array}{l}\mathbf{0 . 9 4 5} \\
(4.52)\end{array}$ & $\begin{array}{l}\mathbf{0 . 7 1 8} \\
(7.60)\end{array}$ & $\begin{array}{l}-0.228 \\
(-1.62)\end{array}$ & $\begin{array}{l}\mathbf{0 . 6 0 6} \\
(3.64)\end{array}$ & $\begin{array}{l}\mathbf{0 . 4 3 1} \\
(4.46)\end{array}$ & $\begin{array}{l}-0.176 \\
(-1.39)\end{array}$ & $\begin{array}{l}\mathbf{0 . 5 2 3} \\
(2.96)\end{array}$ & $\begin{array}{l}\mathbf{0 . 4 7 8} \\
(5.75)\end{array}$ & $\begin{array}{l}-0.045 \\
(-0.33)\end{array}$ \\
\hline LOW & $\begin{array}{l}\mathbf{0 . 5 4 7} \\
(3.65)\end{array}$ & $\begin{array}{l}\mathbf{0 . 5 2 6} \\
(4.37)\end{array}$ & $\begin{array}{l}-0.021 \\
(-0.17)\end{array}$ & $\begin{array}{l}0.143 \\
(0.63)\end{array}$ & $\begin{array}{l}\mathbf{0 . 3 4 3} \\
(2.08)\end{array}$ & $\begin{array}{l}0.200 \\
(1.46)\end{array}$ & $\begin{array}{l}0.433 \\
(1.92)\end{array}$ & $\begin{array}{l}\mathbf{0 . 3 8 9} \\
(2.38)\end{array}$ & $\begin{array}{l}-0.045 \\
(-0.40)\end{array}$ \\
\hline HIGH-LOW & $\begin{array}{l}-0.112 \\
(-0.39)\end{array}$ & $\begin{array}{l}0.366 \\
(1.87)\end{array}$ & $\begin{array}{l}0.478 \\
(1.90)\end{array}$ & $\begin{array}{l}0.080 \\
(0.25)\end{array}$ & $\begin{array}{l}\mathbf{0 . 4 7 8} \\
(2.17)\end{array}$ & $\begin{array}{l}0.398 \\
(1.51)\end{array}$ & $\begin{array}{l}-0.407 \\
(-1.33)\end{array}$ & $\begin{array}{l}0.297 \\
(1.32)\end{array}$ & $\begin{array}{l}\mathbf{0 . 7 0 5} \\
(2.69)\end{array}$ \\
\hline
\end{tabular}

Bold values denote statistical significance at the $5 \%$ level. Corresponding $t$-statistics are shown in parentheses.

the long-short factors have higher average returns. We extend these studies by investigating this issue for both CS and TS factor momentum strategies.

To test for the influence of investor sentiment, we methodologically follow Hao et al (2018) and Antoniou et al (2013) by regressing factor momentum returns on investor sentiment dummy variables using the one-month lagged value of Baker and Wurgler's (2006) investor sentiment index. Dummy variable $\mathrm{HIGH}_{t}\left(\mathrm{LOW}_{t}\right)$ equals one when the value of investor sentiment index at the end of month $t-1$ belongs to the top (bottom) $30 \%$ of all observations and zero otherwise. Dummy variable MILD $_{t}$ equals one when the investor sentiment index is above the bottom $30 \%$ but below the top $30 \%$ and zero otherwise. The value of investor sentiment index at month $t$ measures the investor sentiment at the end of the month, such that the lagged value of investor sentiment gives the contemporaneous value of investor sentiment at the beginning of month $t$. The aforementioned authors used a weighted three-month rolling average of investor sentiment index to assess the level of investor sentiment at the end of the formation period. Because the three-month average can level off sharp changes in the investor sentiment index, we use the raw month-end values of the investor sentiment index. ${ }^{23}$

\footnotetext{
23 The results are very similar (not reported) using the three-month rolling average.
}

To test whether the average factor momentum returns are significantly different from zero in the month following high, mild, and low investor sentiment, the factor momentum returns are regressed on sentiment dummy variables without a constant in the following form:

$F_{M O M}{ }_{i, t}=\alpha_{1} \mathrm{HIGH}_{t}+\alpha_{2} \mathrm{MILD}_{t}+\alpha_{3} \mathrm{LOW}_{t}+\varepsilon_{t}$,

where $F M O M_{i, t}$ is the return of factor momentum portfolio $i$ in month $t$, and $\alpha_{1}, \alpha_{2}$, and $\alpha_{3}$ are the coefficient estimates on dummy variables $\mathrm{HIGH}_{t}, \mathrm{MILD}_{t}$, and $\mathrm{LOW}_{t}$, respectively. Coefficient estimates capture the average factor momentum returns following each investor sentiment. To test whether the average factor momentum returns in high sentiment periods are statistically different from returns in low sentiment periods, the monthly factor momentum returns are regressed on dummy variables $\mathrm{HIGH}_{\mathrm{t}}$ and $\mathrm{MILD}_{\mathrm{t}}$ with a constant $\left(\alpha_{0}\right)$ in the following form:

FMOM $_{i, t}=\alpha_{0}+\alpha_{1} \mathrm{HIGH}_{t}+\alpha_{2} \mathrm{MILD}_{t}+\varepsilon_{t}$,

where the estimate of $\alpha_{1}$ measures the difference in average returns between periods of high and low investor sentiment.

Table 10 reports the regression estimates for factor momentum portfolios conditional on high, mild, and low investor sentiment. The investor sentiment index has a zero 
mean and median close to zero (0.024). Regression estimates are reported for the long-short factor portfolio, in addition to separate estimates for winner and loser portfolios. The sample period is August 1965 to December 2018. The $t$-statistics are calculated using the robust standard errors of Newey and West (1987) and reported in parentheses (with bold values indicating statistical significance on the 5\% level).

While Ehsani and Linnainmaa (2019) found that winnerfactor portfolios have similar performance in high and low investor sentiment states, our results indicate that winnerfactor portfolios formed using six-month lagged returns (CS 6-1 and TS 6-1) have significantly higher returns following periods of high investor sentiment. Furthermore, the returns of all winner-factor portfolios are positively correlated with investor sentiment. The returns of loser-factor portfolios exhibit larger variation between investor sentiment states and, similar to the returns of winner-factor portfolios, are always highest following periods of high investor sentiment. Conversely, the returns of loser-factor portfolios are not significantly negative following periods of low investor sentiment. These findings are consistent with those in Ehsani and Linnainmaa (2019).

Second, the returns of long-short factor momentum portfolios (FMOM) are not significantly different between high and low investor sentiment states. While differences in average long-short factor momentum portfolio returns between high and low sentiment are negative for four-out-of-six strategies, none of the differences is statistically significant. The long-short CS 1-1 strategy has statistically significant average returns in all investor sentiment states, whereas the other long-short portfolios lose statistical significance either in high or low (or both) sentiment states.

Although the performance of long-short factor momentum is not significantly affected by prevailing investor sentiment, our results suggest that factor momentum is driven by mispricing. Winner-factor portfolios capture mispricing in all sentiment states. However, because winner-factors have higher average returns following periods of high investor sentiment and loser factors have significant average returns only following high investor sentiment, we infer that mispricing is more pronounced when investor sentiment is high. As suggested by Stambaugh et al (2012), the fact that mispricing is affected by investor sentiment has important implications for factor momentum strategies. Following periods of high investor sentiment, betting against the loser factors-while the mispricing is at its strongest-decreases the performance of long-short factor momentum. This effect is more pronounced when the formation or holding period is longer than a month. When investor sentiment is low and mispricing is less pronounced, the returns of loser factors tend to reverse, such that betting against loser-factors increases the profitability of factor momentum.
To provide further evidence on mispricing as a partial explanation for factor momentum payoffs, we employ the recently proposed three-factor model of Daniel et al (2019, DH3) for risk adjustment. This model is comprised of market (MKT), financing (FIN), and post-earnings announcement drift (PEAD) factors. FIN is defined as a composite of the 1-year net-share-issuance (NSI) and 5-year compositeshare-issuance (CSI) measures (see Pontiff and Woodgate, 2008; Daniel and Titman, 2006). The factor is based on twoby-three sorts on size and the financing characteristic which is a 50/50 combination of the NSI and CSI measures. It goes long the two value-weighted low-issuance portfolios and short the two high-issuance portfolios. PEAD is constructed as long firms with positive earnings surprises and short firms with negative surprises. Monthly return series for the FIN and PEAD factors from July 1972 to December 2018 are obtained from Daniel's website. ${ }^{24}$ The DH3 model is:

FMOM $_{i}=\alpha_{i}+b_{i} M K T+c_{i} F I N+d_{i} P E A D+\varepsilon_{i}$.

Based on these asset pricing tests, we would expect to find that the DH3 model increases the explanatory power with respect to factor momentum returns over FF6 models. To the extent that factor momentum returns stem from mispricing, a significant exposure to the PEAD factor would suggest that investors underreact to earnings-related information. Following the interpretation of Daniel et al (2019), overpriced portfolios should have negative loadings on the FIN and PEAD factors, and underpriced portfolios should have positive loadings. The results are reported in Table 11. Because the sample period is shorter than previously, the first row reports the unconditional average returns for the subsample. Panel A reports the regression results using the DH3 model, and for comparison, Panel B reports the regression results using the FF6 model.

Panel A shows that the DH3 model explains factor momentum returns better than the FF6 model. That is, the alphas are lower for all CS and TS strategies and their statistical significance is lower than in the FF6 model regressions. All factor momentum strategies, except CS 1-1, have significant high loadings on the PEAD factor. Panel B shows that the FF6 model alphas are similar to those in Table 6, but their $t$-statistics are slightly lower due to the shorter sample period. The factor loadings are similar in the subsample as in the full sample period also. To test whether the winnerand loser-factor portfolios have different exposures to the DH3 model, Table 12 repeats the DH3 model regression separately for the winner- and loser-factor portfolios.

The estimates in Table 12 show that winner-factor (loserfactor) portfolios have significantly positive (negative) exposure to the PEAD factor. These findings suggest that the

\footnotetext{
${ }^{24}$ http://www.kentdaniel.net/data.php.
} 
Table 11 DH3 and FF6 model regressions for factor momentum portfolios

\begin{tabular}{|c|c|c|c|c|c|c|c|}
\hline Mean & $\begin{array}{l}\text { CS 1-1 } \\
1.064\end{array}$ & $\begin{array}{l}\text { TS 1-1 } \\
0.653\end{array}$ & $\begin{array}{l}\text { CS 6-1 } \\
0.653\end{array}$ & $\begin{array}{l}\text { TS 6-1 } \\
0.303\end{array}$ & $\begin{array}{l}\text { CS 12-1 } \\
0.613\end{array}$ & $\begin{array}{l}\text { TS } 12-1 \\
0.358\end{array}$ & $\begin{array}{l}\text { CS 6-6 } \\
0.619\end{array}$ \\
\hline \multicolumn{8}{|c|}{ Panel A: DH3 model } \\
\hline Alpha & $\begin{array}{l}\mathbf{0 . 7 1 2} \\
(2.56)\end{array}$ & $\begin{array}{l}\mathbf{0 . 4 3 7} \\
(2.23)\end{array}$ & $\begin{array}{l}0.245 \\
(1.18)\end{array}$ & $\begin{array}{l}0.021 \\
(0.13)\end{array}$ & $\begin{array}{l}0.167 \\
(0.73)\end{array}$ & $\begin{array}{l}0.009 \\
(0.06)\end{array}$ & $\begin{array}{l}-0.026 \\
(-0.08)\end{array}$ \\
\hline MKT-RF & $\begin{array}{l}-0.037 \\
(-0.52)\end{array}$ & $\begin{array}{l}-0.081 \\
(-1.44)\end{array}$ & $\begin{array}{l}0.006 \\
(0.07)\end{array}$ & $\begin{array}{l}-0.070 \\
(-1.16)\end{array}$ & $\begin{array}{l}0.026 \\
(0.31)\end{array}$ & $\begin{array}{l}-0.008 \\
(-0.13)\end{array}$ & $\begin{array}{l}0.080 \\
(0.61)\end{array}$ \\
\hline FIN & $\begin{array}{l}0.187 \\
(1.71)\end{array}$ & $\begin{array}{l}0.096 \\
(0.92)\end{array}$ & $\begin{array}{l}-0.041 \\
(-0.39)\end{array}$ & $\begin{array}{l}-0.087 \\
(-0.62)\end{array}$ & $\begin{array}{l}-0.047 \\
(-0.33)\end{array}$ & $\begin{array}{l}-0.032 \\
(-0.27)\end{array}$ & $\begin{array}{l}-0.041 \\
(-0.23)\end{array}$ \\
\hline PEAD & $\begin{array}{l}0.375 \\
(1.61)\end{array}$ & $\begin{array}{l}\mathbf{0 . 3 0 3} \\
(2.15)\end{array}$ & $\begin{array}{l}\mathbf{0 . 7 0 4} \\
(4.68)\end{array}$ & $\begin{array}{l}\mathbf{0 . 6 1 9} \\
(3.67)\end{array}$ & $\begin{array}{l}\mathbf{0 . 7 5 4} \\
(4.99)\end{array}$ & $\begin{array}{l}\mathbf{0 . 6 0 9} \\
(4.87)\end{array}$ & $\begin{array}{l}\mathbf{1 . 0 2 1} \\
(5.50)\end{array}$ \\
\hline Adjusted $R^{2}$ & 0.049 & 0.062 & 0.098 & 0.142 & 0.109 & 0.139 & 0.082 \\
\hline \multicolumn{8}{|c|}{ Panel B: FF6 model } \\
\hline Alpha & $\begin{array}{l}\mathbf{0 . 8 4 7} \\
(3.96)\end{array}$ & $\begin{array}{l}\mathbf{0 . 5 1 0} \\
(3.12)\end{array}$ & $\begin{array}{l}\mathbf{0 . 3 8 8} \\
(2.06)\end{array}$ & $\begin{array}{l}0.100 \\
(0.73)\end{array}$ & $\begin{array}{l}0.203 \\
(1.40)\end{array}$ & $\begin{array}{l}0.049 \\
(0.49)\end{array}$ & $\begin{array}{l}0.076 \\
(0.26)\end{array}$ \\
\hline MKT-RF & $\begin{array}{l}-0.028 \\
(-0.43)\end{array}$ & $\begin{array}{l}-0.063 \\
(-1.33)\end{array}$ & $\begin{array}{l}0.006 \\
(0.09)\end{array}$ & $\begin{array}{l}-0.046 \\
(-1.09)\end{array}$ & $\begin{array}{l}0.031 \\
(0.60)\end{array}$ & $\begin{array}{l}0.012 \\
(0.34)\end{array}$ & $\begin{array}{l}0.055 \\
(0.61)\end{array}$ \\
\hline SMB & $\begin{array}{l}0.011 \\
(0.12)\end{array}$ & $\begin{array}{l}0.021 \\
(0.31)\end{array}$ & $\begin{array}{l}0.123 \\
(1.82)\end{array}$ & $\begin{array}{l}0.102 \\
(1.43)\end{array}$ & $\begin{array}{l}\mathbf{0 . 2 0 8} \\
(3.33)\end{array}$ & $\begin{array}{l}\mathbf{0 . 1 3 2} \\
(2.30)\end{array}$ & $\begin{array}{l}\mathbf{0 . 3 2 6} \\
(3.19)\end{array}$ \\
\hline HML & $\begin{array}{l}-0.152 \\
(-1.34)\end{array}$ & $\begin{array}{l}-0.103 \\
(-1.15)\end{array}$ & $\begin{array}{l}0.056 \\
(0.45)\end{array}$ & $\begin{array}{l}0.011 \\
(0.12)\end{array}$ & $\begin{array}{l}-0.011 \\
(-0.09)\end{array}$ & $\begin{array}{l}-0.027 \\
(-0.35)\end{array}$ & $\begin{array}{l}0.173 \\
(0.83)\end{array}$ \\
\hline RMW & $\begin{array}{l}0.170 \\
(0.99)\end{array}$ & $\begin{array}{l}0.032 \\
(0.23)\end{array}$ & $\begin{array}{l}-0.208 \\
(-1.57)\end{array}$ & $\begin{array}{l}-\mathbf{0 . 3 1 5} \\
(-2.04)\end{array}$ & $\begin{array}{l}-0.179 \\
(-1.92)\end{array}$ & $\begin{array}{l}-\mathbf{0 . 1 9 0} \\
(-2.11)\end{array}$ & $\begin{array}{l}-0.227 \\
(-1.16)\end{array}$ \\
\hline CMA & $\begin{array}{l}\mathbf{0 . 6 0 0} \\
(3.85)\end{array}$ & $\begin{array}{l}\mathbf{0 . 4 5 7} \\
(3.92)\end{array}$ & $\begin{array}{l}-0.119 \\
(-0.69)\end{array}$ & $\begin{array}{l}0.045 \\
(0.33)\end{array}$ & $\begin{array}{l}-0.138 \\
(-1.15)\end{array}$ & $\begin{array}{l}0.081 \\
(0.93)\end{array}$ & $\begin{array}{l}-0.466 \\
(-1.55)\end{array}$ \\
\hline UMD & $\begin{array}{l}0.071 \\
(0.46)\end{array}$ & $\begin{array}{l}0.086 \\
(0.90)\end{array}$ & $\begin{array}{l}\mathbf{0 . 4 8 7} \\
(4.98)\end{array}$ & $\begin{array}{l}\mathbf{0 . 4 2 8} \\
(7.67)\end{array}$ & $\begin{array}{l}\mathbf{0 . 7 0 0} \\
(11.45)\end{array}$ & $\begin{array}{l}\mathbf{0 . 4 8 6} \\
(14.10)\end{array}$ & $\begin{array}{l}\mathbf{0 . 9 3 4} \\
(6.64)\end{array}$ \\
\hline Adjusted $R^{2}$ & 0.052 & 0.077 & 0.261 & 0.372 & 0.543 & 0.513 & 0.392 \\
\hline
\end{tabular}

Bold values denote statistical significance at the 5\%-level. Corresponding $t$-statistics are shown in parentheses
Table 12 DH3 model regressions for winner- and loser-factor portfolios

\begin{tabular}{|c|c|c|c|c|c|c|c|}
\hline & CS $1-1$ & TS $1-1$ & CS 6-1 & TS 6-1 & CS $12-1$ & TS $12-1$ & CS 6-6 \\
\hline \multicolumn{8}{|c|}{ Panel A: Winner-factor portfolios (long) } \\
\hline Alpha & $\begin{array}{l}\mathbf{0 . 6 1 0} \\
(4.38)\end{array}$ & $\begin{array}{l}\mathbf{0 . 4 9 9} \\
(5.70)\end{array}$ & $\begin{array}{l}\mathbf{0 . 4 1 0} \\
(3.31)\end{array}$ & $\begin{array}{l}\mathbf{0 . 2 3 8} \\
(2.60)\end{array}$ & $\begin{array}{l}\mathbf{0 . 4 4 6} \\
(3.46)\end{array}$ & $\begin{array}{l}\mathbf{0 . 2 6 5} \\
(2.89)\end{array}$ & $\begin{array}{l}\mathbf{0 . 5 1 2} \\
(2.33)\end{array}$ \\
\hline MKT-RF & $\begin{array}{l}-0.026 \\
(-0.72)\end{array}$ & $\begin{array}{l}-0.041 \\
(-1.39)\end{array}$ & $\begin{array}{l}-0.032 \\
(-0.74)\end{array}$ & $\begin{array}{l}-0.052 \\
(-1.47)\end{array}$ & $\begin{array}{l}-0.002 \\
(-0.04)\end{array}$ & $\begin{array}{l}-0.041 \\
(-1.26)\end{array}$ & $\begin{array}{l}-0.024 \\
(-0.35)\end{array}$ \\
\hline FIN & $\begin{array}{l}\mathbf{0 . 3 5 4} \\
(7.04)\end{array}$ & $\begin{array}{l}\mathbf{0 . 2 4 1} \\
(3.99)\end{array}$ & $\begin{array}{l}\mathbf{0 . 2 1 3} \\
(2.76)\end{array}$ & $\begin{array}{l}0.135 \\
(1.29)\end{array}$ & $\begin{array}{l}\mathbf{0 . 2 1 4} \\
(2.46)\end{array}$ & $\begin{array}{l}\mathbf{0 . 1 6 4} \\
(2.04)\end{array}$ & $\begin{array}{l}\mathbf{0 . 4 7 8} \\
(4.12)\end{array}$ \\
\hline PEAD & $\begin{array}{l}0.177 \\
(1.58)\end{array}$ & $\begin{array}{l}\mathbf{0 . 1 1 3} \\
(1.98)\end{array}$ & $\begin{array}{l}\mathbf{0 . 4 0 1} \\
(5.30)\end{array}$ & $\begin{array}{l}\mathbf{0 . 3 3 7} \\
(2.58)\end{array}$ & $\begin{array}{l}\mathbf{0 . 3 4 6} \\
(4.05)\end{array}$ & $\begin{array}{l}\mathbf{0 . 2 7 4} \\
(3.04)\end{array}$ & $\begin{array}{l}\mathbf{0 . 6 0 2} \\
(4.79)\end{array}$ \\
\hline Adjusted $R^{2}$ & 0.277 & 0.299 & 0.191 & 0.207 & 0.155 & 0.242 & 0.227 \\
\hline \multicolumn{8}{|c|}{ Panel B: Loser-factor portfolios (short) } \\
\hline Alpha & $\begin{array}{l}-0.102 \\
(-0.62)\end{array}$ & $\begin{array}{l}0.062 \\
(0.45)\end{array}$ & $\begin{array}{l}0.165 \\
(1.31)\end{array}$ & $\begin{array}{l}0.217 \\
(1.75)\end{array}$ & $\begin{array}{l}\mathbf{0 . 2 7 9} \\
(2.20)\end{array}$ & $\begin{array}{l}\mathbf{0 . 2 5 6} \\
(2.17)\end{array}$ & $\begin{array}{l}\mathbf{0 . 5 3 8} \\
(2.81)\end{array}$ \\
\hline MKT-RF & $\begin{array}{l}0.011 \\
(0.27)\end{array}$ & $\begin{array}{l}0.039 \\
(1.12)\end{array}$ & $\begin{array}{l}-0.038 \\
(-0.93)\end{array}$ & $\begin{array}{l}0.018 \\
(0.47)\end{array}$ & $\begin{array}{l}-0.028 \\
(-0.66)\end{array}$ & $\begin{array}{l}-0.034 \\
(-0.89)\end{array}$ & $\begin{array}{l}-0.104 \\
(-1.42)\end{array}$ \\
\hline FIN & $\begin{array}{l}\mathbf{0 . 1 6 7} \\
(2.27)\end{array}$ & $\begin{array}{l}\mathbf{0 . 1 4 5} \\
(2.64)\end{array}$ & $\begin{array}{l}\mathbf{0 . 2 5 4} \\
(5.41)\end{array}$ & $\begin{array}{l}\mathbf{0 . 2 2 2} \\
(4.90)\end{array}$ & $\begin{array}{l}\mathbf{0 . 2 6 1} \\
(4.27)\end{array}$ & $\begin{array}{l}\mathbf{0 . 1 9 6} \\
(4.51)\end{array}$ & $\begin{array}{l}\mathbf{0 . 5 1 9} \\
(6.01)\end{array}$ \\
\hline PEAD & $\begin{array}{l}-0.197 \\
(-1.50)\end{array}$ & $\begin{array}{l}-\mathbf{0 . 1 9 0} \\
(-2.08)\end{array}$ & $\begin{array}{l}-\mathbf{0 . 3 0 3} \\
(-3.50)\end{array}$ & $\begin{array}{c}-\mathbf{0 . 2 8 3} \\
(-4.70)\end{array}$ & $\begin{array}{c}-\mathbf{0 . 4 0 8} \\
(-5.26)\end{array}$ & $\begin{array}{l}-\mathbf{0 . 3 3 5} \\
(-6.16)\end{array}$ & $\begin{array}{l}-\mathbf{0 . 4 1 9} \\
(-3.45)\end{array}$ \\
\hline Adjusted $R^{2}$ & 0.061 & 0.074 & 0.229 & 0.203 & 0.255 & 0.235 & 0.313 \\
\hline
\end{tabular}

Bold values denote statistical significance at the 5\% level. Corresponding $t$-statistics are shown in parentheses 
returns of prior winner-factor portfolios appear to stem from positive earnings surprises, whereas the returns of loser-factor portfolios arise from negative earnings surprises. To the extent that the PEAD factor captures mispricing, winner factors profit from being long underpriced stocks and short overpriced stocks. Conversely, loser-factors' negative exposures to the PEAD factor suggests that loser factors capture mispricing by being long overpriced stocks and short underpriced stocks.

These findings and interpretations are consistent with the expectation that, on average, individual long-short factors capture mispricing by being long underpriced stocks and short overpriced stocks. When long-short factor returns turn negative, previously overpriced (underpriced) stocks have become underpriced (overpriced). If the mispricing continues in the short term, factor momentum portfolios profit by trading the factor oppositely to its long-term average. This means shorting the stocks that are now overpriced and buying the stocks that are relatively underpriced. Moreover, the returns of the loser-factor portfolios increase with the length of the formation period, suggesting that the short-term contrary mispricing is not as persistent as long-term mispricing.

\section{Practical implications}

How can factor momentum strategies be implemented by investors? Unlike factor momentum strategies that are longshort portfolios, we propose that long-only factor momentum portfolios could be feasible as an investment strategy. As shown in Table 4, for five-out-of-eight factor momentum strategies the short side is statistically not different from zero, implying that the profitability of the long-short factor momentum portfolios is mainly driven by the long side. For instance, the long-leg of the CS $1-1$ strategy is $0.90 \%$ per month and with a robust $t$-statistic of 8.95 indicating statistical significance on any level, whereas the short-leg is $-0.09 \%$ per month and statistically insignificant. An investor implementing this strategy could employ exchange traded funds (ETFs) that track those factors. Institutional investors face standard trading fees that will slightly diminish the overall portfolio return. Grobys et al (2018), who explored the profitability of risk-managed industry-momentum strategies, estimated that the average turnover of those strategies varies between 46.30 and $63.05 \%$. Being conservative and using the upper bound (63.05\%) times 14 bps trading costs as in Moreira and Muir (2017), the sample average return decreases by $0.09 \%$ per month. Implementing the CS 1-1 strategy as a long-only strategy, the net-payoff is $0.81 \%$ per month. Even assuming that the overall factor momentum portfolio needs to be liquidated and re-invested every month, the strategy generates a monthly net-payoff of $0.62 \%$ per month with a high $t$-statistic of 6.16 . Additionally, by implementing factor momentum as long-only strategy, there are no further credit costs involved.

\section{Conclusion}

In view of previous research on stock price and factor momentum, the present study sought to investigate: (1) the profitability of option-implied, volatility-managed factor momentum strategies; (2) whether factor momentum strategies or their option-implied volatility-managed counterparts are subject to the same type of crash risks as stock price momentum strategies; and (3) the origins of factor momentum with respect to investor sentiment. Preliminary analyses indicated that factor returns are positively autocorrelated but cross-sectional correlations between factor returns are generally low. Factor returns were predictable from prior 1- and 12-month returns, and negative factor returns did not appear exhibit longevity. By implication, betting that prior 1- to 12-month winner factors continue to perform well is profitable, whereas betting against recent loser factors are not. Also, because factors have generally low or even negative correlations, factor momentum strategies can be constructed with a relatively low number of factors. Since factor momentum returns are mainly driven by the long-leg, we show that factor momentum could be practically implemented as a longonly strategy using ETFs.

We found that factor momentum portfolios generated substantial returns that exceeded the returns of individual factors. Controlling for the Fama and French (2018) six-factor model, three-out-of-seven factor momentum portfolios had statistically significant alphas, and two of the factor momentum portfolios had significant alphas after controlling for the three-factor model of Daniel et al (2019). Both CS and TS strategies performed best with one-month formation and holding periods. Contrary to the results of Gupta and Kelly (2019) and Ehsani and Linnainmaa (2019), we found that CS strategies have higher average returns than TS strategies. Furthermore, the CS and TS portfolios that are formed using 1-month lagged returns had robust excess returns in all cases.

Consistent with Stambaugh et al (2012), average longshort factor momentum returns were generally highest following periods of high investor sentiment when short-side portfolios become relatively more overpriced than long-side portfolios. Regressing factor momentum returns on the three-factor model of Daniel and Hirshleifer (2019) revealed that the returns of winner-factor portfolios appeared to be driven by positive earnings surprises, whereas the returns of loser-factor portfolios arose from negative earnings surprises. Risk-managed factor momentum portfolios had statistically significant alphas relative to unscaled portfolios. Although virtually all factor momentum portfolios did not exhibit optionality effects in bear markets, the average returns of factor momentum 
portfolios can be increased and return volatility lowered using option-implied market volatility to scale the portfolio weights. Optionality regressions showed that factor momentum portfolios generally had significant market risk, which was partially removed with volatility scaling.

Funding Open access funding provided by University of Vaasa (UVA).

Open Access This article is licensed under a Creative Commons Attribution 4.0 International License, which permits use, sharing, adaptation, distribution and reproduction in any medium or format, as long as you give appropriate credit to the original author(s) and the source, provide a link to the Creative Commons licence, and indicate if changes were made. The images or other third party material in this article are included in the article's Creative Commons licence, unless indicated otherwise in a credit line to the material. If material is not included in the article's Creative Commons licence and your intended use is not permitted by statutory regulation or exceeds the permitted use, you will need to obtain permission directly from the copyright holder. To view a copy of this licence, visit http://creativecommons.org/licenses/by/4.0/.

\section{References}

Antoniou, C., J.A. Doukas, and A. Subrahmanyam. 2013. Cognitive dissonance, sentiment, and momentum. Journal of Financial and Quantitative Analysis 48 (1): 245-275.

Arnott, R. D., Clements, M., Kalesnik, V., and J. Linnainmaa. 2018. Factor momentum. SSRN working paper, available at SSRN: https:// ssrn.com/abstract $=3116974$.

Asness, C.S., and A. Frazzini. 2013. The devil in HML's details. Journal of Portfolio Management 39 (4): 49-68.

Asness, C.S., A. Frazzini, and L.H. Pedersen. 2019. Quality minus junk. Review of Accounting Studies 24 (1): 34-112.

Asness, C.S., T.J. Moskowitz, and L.H. Pedersen. 2013. Value and momentum everywhere. Journal of Finance 68 (3): 929-985.

Avramov, D., S. Cheng, A. Schreiber, and K. Shemer. 2017. Scaling up market anomalies. Journal of Investing 26 (3): 89-105.

Baker, M., and J. Wurgler. 2006. Investor sentiment and the cross-section of stock returns. Journal of Finance 61 (4): 1645-1680.

Baltas, N. 2015. Trend-following, risk-parity and the influence of correlations. In Jurczenko, E. (Ed) Risk-Based and Factor Investing, 1st edition. Elsevier/ISTE Press, London, 65-96.

Baltas, N., and R. Kosowski. 2015. Demystifying time-series momentum strategies: Volatility estimators, trading rules and pairwise correlations. SSRN working paper, available at SSRN: https://ssrn.com/ abstract $=2140091$.

Barroso, P., and P. Santa-Clara. 2015. Momentum has its moments. Journal of Financial Economics 116 (1): 111-120.

Basu, S. 1983. The relationship between earnings yield, market value and return for NYSE common stocks: Further evidence. Journal of Financial Economics 12 (180): 129-156.

Cboe. 2019. Cboe volatility index-VIX White Paper. Retrieved from http://www.cboe.com/micro/vix/vixwhite.pdf.

Christensen, B., and N. Prabhala. 1998. The relation between implied and realized volatility. Journal of Financial Economics 50 (2): 125-150.

Cooper, M.J., H. Gulen, and M.J. Schill. 2008. Asset growth and the cross-section of stock returns. Journal of Finance 63 (4): 1609-1651.

Daniel, K., D. Hirshleifer, and L. Sun. 2019. Short- and long-horizon behavioral factors. Review of Financial Studies 33 (4): 1673-1736.

Daniel, K., and T.J. Moskowitz. 2016. Momentum crashes. Journal of Financial Economics 122 (2): 221-247.
Daniel, K.D., and S. Titman. 2006. Market reactions to tangible and intangible information. Journal of Finance 61 (4): 1605-1643.

Dudler, M., B. Gmur, and S. Malamud. 2015. Risk adjusted time series momentum. Journal of Alternative Investments 18: 91-103.

Ehsani, S., and J. Linnainmaa. 2019. Factor momentum and the momentum factor. NBER Working Papers 25551, National Bureau of Economic Research, Inc.

Fama, E.F., and K.R. French. 2015. A five-factor asset pricing model. Journal of Financial Economics 116 (1): 1-22.

Fama, E.F., and K.R. French. 2018. Choosing factors. Journal of Financial Economics 128 (2): 234-252.

Frazzini, A., and L.H. Pedersen. 2014. Betting against beta. Journal of Financial Economics 111 (1): 1-25.

Grobys, K., and J. Kolari. 2020. On industry momentum strategies. Journal of Financial Research 43 (1): 95-119.

Grobys, K., J. Ruotsalainen, and J. Äijö. 2018. Risk-managed industry momentum and momentum crashes. Quantitative Finance 18 (10): $1715-1733$.

Gupta, T., and B. Kelly. 2019. Factor momentum everywhere. Journal of Portfolio Management 45 (3): 13-36.

Hao, Y., R.K. Chou, K.C. Ko, and N.T. Yang. 2018. The 52-week high, momentum, and investor sentiment. International Review of Financial Analysis 57 (5): 167-183.

Hou, K., C. Xue, and L. Zhang. 2020. Replicating anomalies. Review of Financial Studies 33 (5): 2019-2133.

Jacobs, H., Regele, T., and M. Weber. 2015. Expected skewness and momentum. SSRN working paper, available at SSRN: https://ssrn. com/abstract $=2600014$.

Jegadeesh, N. 1990. Evidence of predictable behavior of security returns. Journal of Finance 45 (3): 881-898.

Jegadeesh, N., and S. Titman. 1993. Returns to buying winners and selling losers: Implications for stock market efficiency. Journal of Finance 48 (1): 65-91.

Kim, A.Y., Y. Tse, and J.K. Wald. 2016. Time series momentum and volatility scaling. Journal of Financial Markets 30 (9): 103-124.

Lakonishok, J., A. Shleifer, and W.V. Robert. 1994. Investment, extrapolation, and risk. Journal of Finance 49 (5): 1541-1578.

Litzenberger, R. H., and K. Ramaswamy. 1979. The effect of personal taxes and dividends on capital asset prices. Theory and empirical evidence. Journal of Financial Economics 7 (2): 163-195.

Liu, F., X. Tang, and G. Zhou. 2019. Volatility-managed portfolio: Does it really work?. Journal of Portfolio Management 46 (1): 38-51.

McAleer, M., and M.C. Medeiros. 2008. Realized volatility: A review. Econometric Reviews 27 (1-3): 10-45.

Mclean, R.D., and J. Pontiff. 2016. Does academic research destroy stock return predictability?. Journal of Finance 71 (1): 5-32.

Moreira, A., and T. Muir. 2017. Volatility-managed portfolios. Journal of Finance 72 (4): 1611-1644.

Moskowitz, T.J., and M. Grinblatt. 1999. Do industries explain momentum?. Journal of Finance 54 (4): 1249-1290.

Newey, W.K., and K.D. West. 1987. A simple, positive semi-definite, heteroskedasticity and autocorrelation consistent covariance matrix. Econometrica 55 (3): 703

Novy-Marx, R. 2013. The other side of value: The gross profitability premium. Journal of Financial Economics 108 (1): 1-28.

Novy-Marx, R. 2014. Predicting anomaly performance with politics, the weather, global warming, sunspots, and the stars. Journal of Financial Economics 112 (2): 137-146.

Plessis, J.P.D., and W.G. Hallerbach. 2017. Volatility weighting applied to momentum strategies. Journal of Alternative Investments 19 (3): $40-58$.

Pontiff, J., and A. Woodgate. 2008. Share issuance and cross-sectional returns. The Journal of Finance 63 (2): 921-945.

Rosenberg, B., K. Reid, and R. Lanstein. 1985. Persuasive evidence of market inefficiency. Journal of Portfolio Management 11 (3): 9-16. 
Stambaugh, R.F., J. Yu, and Y. Yuan. 2012. The short of it: Investor sentiment and anomalies. Journal of Financial Economics 104 (2): 288-302.

Whaley, R.E. 2009. Understanding the VIX. Journal of Portfolio Management 35 (3): 98-105.

Zaremba, A., and J. Shemer. 2018. Is there momentum in factor premia? Evidence from international equity markets. Research in International Business and Finance 4 (12): 120-130.

Publisher's Note Springer Nature remains neutral with regard to jurisdictional claims in published maps and institutional affiliations.
Klaus Grobys is an Adjunct Professor of Economics with specialization in Asset Pricing, University of Jyväskyla, Finland, and has the position as Assistant Professor of Finance at the University of Vaasa, Finland.

James W. Kolari is the JP Morgan Chase Professor of Finance and Academic Director, Commercial Banking Program in the Department of Finance, Mays Business School, Texas A\&M University, USA.

Jere Rutanen holds a M.Sc. in Finance (University of Vaasa) and works currently as Portfolio Management Specialist at Lidl in Espoo (Finland). 